\title{
Examination Corporate Social Responsibility Factors for Supply Chain Management Implementation using GREY-DEMATEL Method
}

\author{
M.Ramaganesh, S.Bathrinath
}

\begin{abstract}
The main purpose of this article is to analyze corporate social responsibility issues in supply chain management implementation. Corporate Social Responsibility is an important activity for organizations to enhance their names socially, economically and environmentally. Analyzing CSR factors in industries is a key and critical factor. This paper aims to present a GREY-DEMATEL approach to identify CSR factors for supply chain management implementation. Nineteen CSR factors were considered from literature surveys and Industry expert's opinions. A direct relationship matrix among factors was arrived at from two different experts with a sound knowledge of social, environmental and economic backgrounds in the auto components manufacturing sector. GREY-DEMATEL approach was used to examine pivotal relationships among factors of CSR issues in successful supply chain management. Based on the relationship matrix, Industrial Relations, Corporate governance, Feminist labour issues, Discrimination and Energy conservation play a major role among factors. Finally, the study concludes with the limitations and the future work of CSR factors in the supply chain implementation process.

Keywords: Corporate Social Responsibility, CSR factors, GREY-DEMATEL, Supply chain management,
\end{abstract}

\section{INTRODUCTION}

I In the business world, much attention is paid to business approaches; aptly defined by Financial Times as "Corporate Social Responsibility" and abbreviated to 'CSR' which contributes to sustainable development by fulfilling economic, social and environmental benefits to all stake holders, going beyond what may be required by regulators or environmental protection groups. Generally, ideas involved in social responsibility and sustainable development were established separately. While social responsibility mostly dealt with social matters sustainable development dealt with environmental issues. CSR covers issues identified by social and environmental reasons issues. CSR practices should be integrated with other organizational structural activities. In recent times, many factors that motivate companies focus on CSR applications. For the implementation of CSR activities,

Revised Manuscript Received on December 05, 2019.

* Correspondence Author

M.Ramaganesh, Department of Mechanical Engineering, Kalasalingam Academy of Research and Education, Krishnankoil, India, Email: ramaganesh87@gmail.com

S.Bathrinath*, Department of Mechanical Engineering, Kalasalingam Academy of Research and Education, Krishnankoil, India. Email: bathri@gmail.com consideration of all the suppliers, manufacturers, and industries involved in the chain link are important. In the product's life cycle process, suppliers, manufacturers are managing their problems on environmental issues on their own. They should not harm the environment through indiscriminate waste disposal uncontrolled letting out of obnoxious gases there by polluting the environs and resulting in non-complying with governmental regulations. The process should also simultaneously reduce cost for sustainable growth through improved profit. Apart from the issues in environment, social issues also play an important role in CSR. Though CSR activities require high investment, to satisfy the customers and improve the productivity and reputation integration of CSR activities in their business process is important. The aim of this research work is to analyze CSR issues in supply chain management and identify the key factors in the Indian auto component sector. Nineteen factors were identified from the literature review and expert's opinion from the industries was taken, for the present study. Then a structure to check the identified factor's relationship was formulated. Influential factors were analyzed through key factors by the help of expert opinion and a pairwise relationship matrix using GREY-DEMATEL. The GREY-DEMATEL method is used to solve the problems which require group decision making in a fuzzy domain. GREY-DEMATEL is an effective method to analyze CSR issues in SCM implementation.

\section{LITERATURE REVIEW}

Kouikoglou et al. [6] presented a fuzzy hierarchical model to assess corporate, social and environmental responsibility. They computed a sustainability index in two multinational cement corporations using a model. Baskaran [1] highlighted the importance of supplier selection by considering CSR issues rather than usual selection criteria consideration of cost, delivery, quality, etc. He considered 6 CSR criteria's like child labour, unfair competition, discrimination, long working hours, pollution and abuse of human rights to measure small scale and medium scaled suppliers who produce products for textile and automotive industries. Seuring et al. [11] projected four important factors to highlight CSR usage over supply chains like (1) defining pressures and incentives for CSR applications across supply chains, (2) classifying and computing the

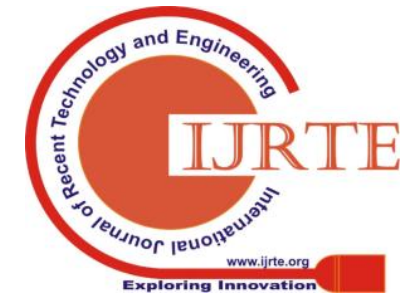


effect of such applications, (3) specifying and handling various problems at the supplier-consumer interface, and (4) handling, applying, and integrating CSR applications into working procedures by considering the entire product's life cycle. Li et al. [7] identified influential indicators in adopting sustainable supply chain management in the auto components manufacturing sector using the DEMATEL approach. They identified that Carbon management indicator played a major role in 15 Sustainable Development indicators arrived at from various literature and experts opinions. Rajak et al. [10] evaluated social sustainability performance in an Indian auto component manufacturing organization using fuzzy logic. They validated the calculated social sustainability index using the conventional crisp approach which helped identify weaker areas and resulted in proposals being developed for social sustainability improvement. Mathiyazhagan et al. [9] used the ISM approach to barrier analysis when applying green supply chain management through a case study in auto components manufacturing industry. Govindan et al. [2] evaluated factors of CSR in the mining industry by a multi-criteria approach. Govindan et al. [3] identified the barriers to implementing a green supply chain based on procurement effectiveness in Indian Industries using Analytic hierarchy process. Govindan et al. [4] reviewed literature related to Multi criteria decision making methods for green supplier evaluation and selection and found that Fuzzy based single model approach was resorted to commonly and found that 'Environmental Management Systems' was the most common criterion considered for green supply selection . Diabat et al. [5] developed a model of factors affecting usage of green supply chain management using Interpretive Structural modeling (ISM). The model was developed and validated through a case study in an Indian manufacturing firm. Vinoth et al. [12] analyzed the effectiveness improvement of agile concept selection which was an exceptional combination of fuzzy decision-making trial and evaluation laboratory (DEMATEL), fuzzy analytical network process (ANP) and fuzzy technique for order preference by similarity for ideal solution (TOPSIS). The approach was discussed by taking a case study from an Indian automotive plastics component manufacturing organization. Luthra et al. [8] developed a Structural model for sustainable consumption and production adoption using a GREY-DEMATEL based approach. It was observed from various literature surveys that only a limited number of factors to the implementation of Green supply chain management were identified. Corporate Social Responsibility (CSR) issues related to supply chain management were not elaborated. It was also seen that alternative Combination of Multi Criteria Decision Making (MCDM) methods/tools could be implemented. Hence, it is important to identify and analyze factors in successful CSR adoptions. This paper gives a development of structural model to assess CSR adoption. To satisfy the above-mentioned research gaps, important CSR adoption factors / barriers were initially renowned from literature and specialists opinions. Then the identified factors were analyzed for the evaluation of connecting relationships among the factors using the GREY-DEMATEL approach. The highlights of this research paper are listed below:

$>$ Identification of mutual CSR factors from literature review and specialists opinions.
$>$ Proposing a framework to analyze CSR factors with GREY-DEMATEL tool.

$>$ Proposed frame work described with case study from a South Indian auto components manufacturing unit which identifies an essential CSR factor.

$>$ Identified essential CSR factors are validated by means of expert's feedback. Then the results were compared with current literature.

\section{PROBLEM FORMULATION}

This study analyzes the CSR factors from the perspective of Social, Environmental Economical and Ethical factors. To solve the problem, a model framework was proposed and it was evaluated with an auto components manufacturing unit in India. Table I shows the identified CSR factors which were developed from various literature surveys and experts opinions from Industry. Then, GREY DEMATEL was used to evaluate these factors.

Table-I: Common Factors of CSR (Corporate Social Responsibility) in supply chain management.

\begin{tabular}{|c|c|c|c|}
\hline $\begin{array}{l}S . \\
\text { No }\end{array}$ & Main Factors & Description & Sub-Factors \\
\hline 1 & Social Factors & $\begin{array}{l}\text { These factors relate } \\
\text { with the social } \\
\text { activities for getting } \\
\text { more support from the } \\
\text { society and improve } \\
\text { the organization's } \\
\text { benefits. }\end{array}$ & $\begin{array}{l}\text { Feminist labour } \\
\text { issue (D6) } \\
\text { Community (D9) } \\
\text { Poverty (D15) } \\
\text { Disaster Relief } \\
\text { (D16) } \\
\text { Women } \\
\text { Empowerment } \\
\text { (D17) } \\
\text { Industrial } \\
\text { Relations (D18) } \\
\text { Support Education } \\
\text { and Healthcare } \\
\text { (D19) }\end{array}$ \\
\hline 2 & $\begin{array}{l}\text { Environmental } \\
\text { Factors }\end{array}$ & $\begin{array}{l}\text { These factors deal with } \\
\text { the environmental } \\
\text { activities to preserve } \\
\text { the nature like green } \\
\text { manufacturing. }\end{array}$ & $\begin{array}{l}\text { Reduce Pollution } \\
\text { (D4) } \\
\text { Energy } \\
\text { Conservation (D5) } \\
\text { Environmental } \\
\text { Degradation (D8) } \\
\text { Worker Health } \\
\text { (D13) }\end{array}$ \\
\hline 3 & $\begin{array}{l}\text { Economical } \\
\text { Factors }\end{array}$ & $\begin{array}{l}\text { These factors indirectly } \\
\text { related with to increase } \\
\text { the organization's } \\
\text { economic function and } \\
\text { its profits by CSR } \\
\text { activities. }\end{array}$ & $\begin{array}{l}\text { Eliminate Unfair } \\
\text { Composition } \\
\text { (D10) } \\
\text { Fair business } \\
\text { (D12) }\end{array}$ \\
\hline 4 & Ethical Factors & $\begin{array}{l}\text { Factors concern things } \\
\text { which are ethically } \\
\text { correct and the } \\
\text { organization's } \\
\text { activities are defined } \\
\text { within the morally } \\
\text { accepted working } \\
\text { boundary areas of the } \\
\text { supply chain } \\
\text { management. } \\
\text { Unethical work should } \\
\text { not be undertaken so } \\
\text { that the organizations } \\
\text { profit is not affected. }\end{array}$ & $\begin{array}{l}\text { Human Rights } \\
\text { issue (D1) } \\
\text { Underage Labour } \\
\text { (D2) } \\
\text { Long Working } \\
\text { hours (D3) } \\
\text { Organizational } \\
\text { legal } \\
\text { responsibilities } \\
\text { (D7) } \\
\text { Discrimination } \\
\text { (D11) } \\
\text { Corporate } \\
\text { governance (D14) }\end{array}$ \\
\hline
\end{tabular}

\section{A. Outline for the study}

Fig 1 shows the outline to identify important factors in the Indian auto components manufacturing sector. First step is identification of common factors which was done by

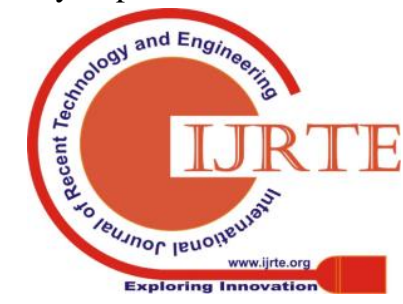


telephonic inquiry, mails, questionnaire and direct meetings from the experience of industrial managers as well as existing literature and experts' opinions. Next step was to analyze the CSR activities in supply chain implementation using the GREY DEMATEL approach. The questionnaire was given to experts with sound knowledge of the social, economic and environment aspects in the auto components manufacturing industry. Then an initial direct relationship matrix was arrived after getting experts' replies. Next, Normalized direct relationship matrix was arrived. Then Total Influential matrix, Prominence and Relation and Cause and Effect of Factors were derived to evaluate essential CSR factors in the auto components manufacturing sector. Next, the results were validated through feedback getting from the industrial experts.

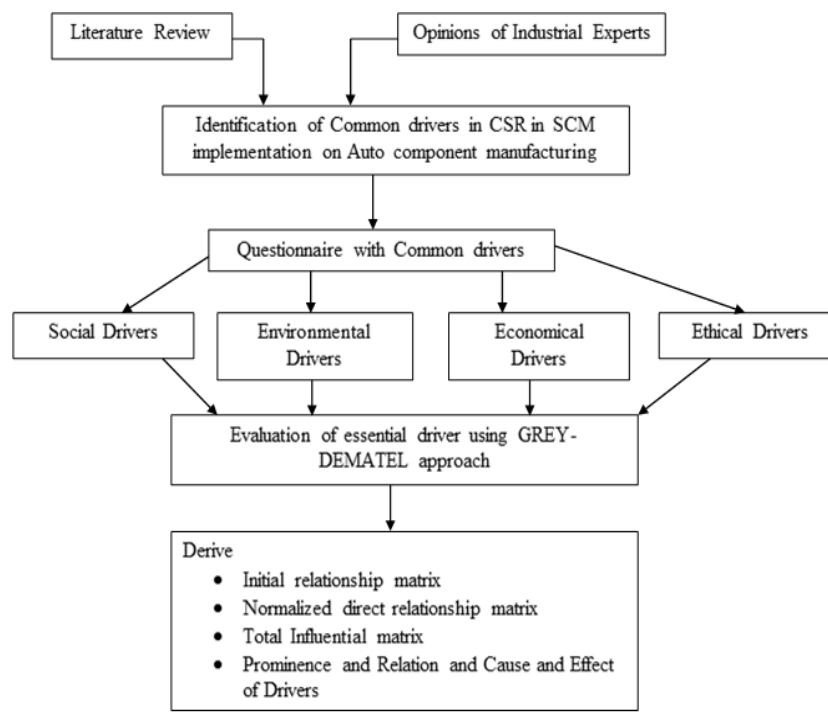

Fig.1. Framework to identify important CSR factors in Supply Chain Management

\section{B. Methodology}

GREY-based DEMATEL method is used in this work to arrive the solution. Grey set concept can be professionally combined with conditions of decision making. DEMATEL strategy gives causal relationships among components with aid of graphs. Here, we apply the combined GREY-DEMATEL method to analyze causal interactions among factors of CSR issues in supply chain management implementation. Steps involved in the GREY DEMATEL method are described below.
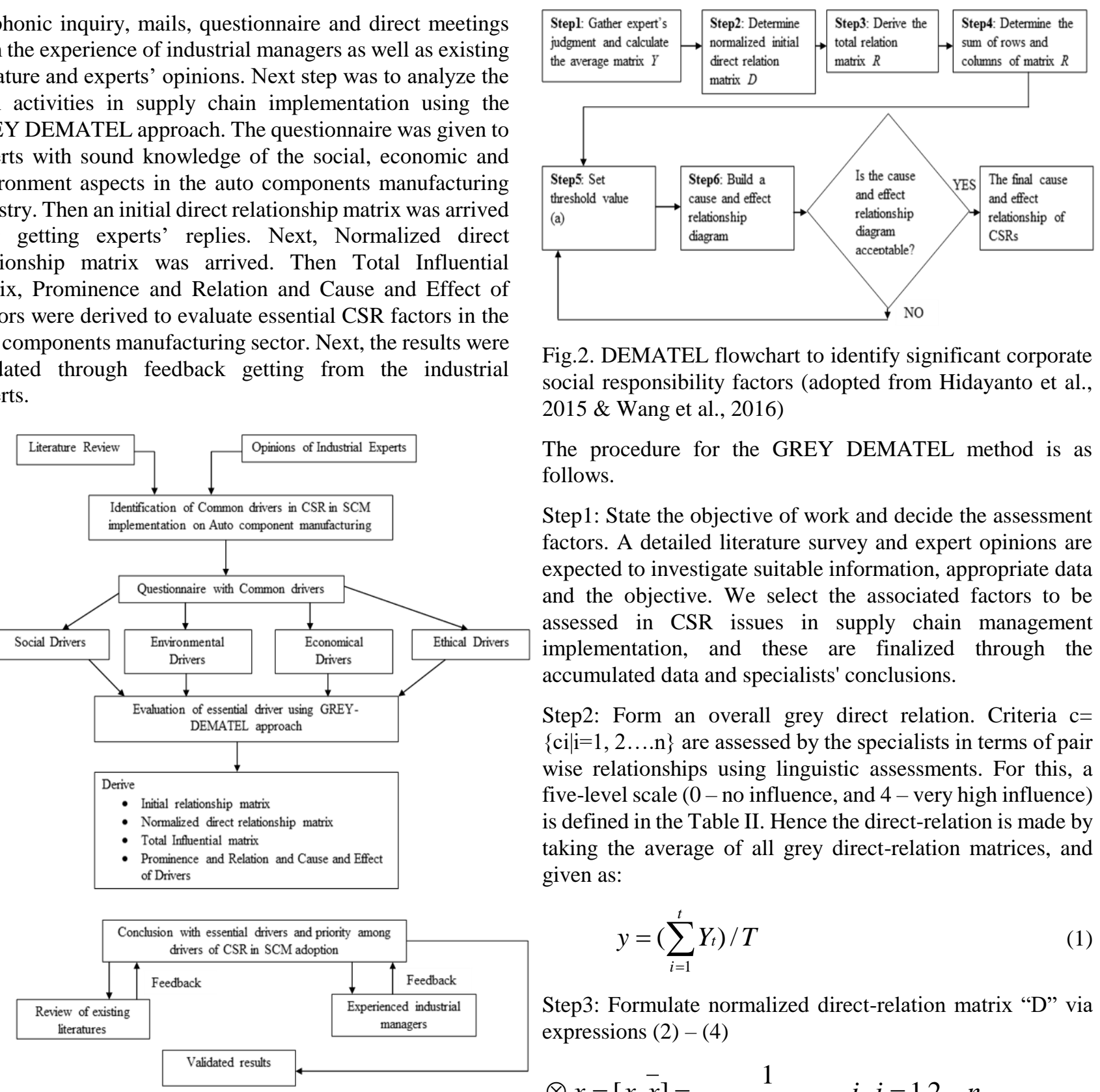

Fig.2. DEMATEL flowchart to identify significant corporate social responsibility factors (adopted from Hidayanto et al., 2015 \& Wang et al., 2016)

The procedure for the GREY DEMATEL method is as follows.

Step1: State the objective of work and decide the assessment factors. A detailed literature survey and expert opinions are expected to investigate suitable information, appropriate data and the objective. We select the associated factors to be assessed in CSR issues in supply chain management implementation, and these are finalized through the accumulated data and specialists' conclusions.

Step2: Form an overall grey direct relation. Criteria $\mathrm{c}=$ $\{\mathrm{ci} \mid \mathrm{i}=1,2 \ldots \mathrm{n}\}$ are assessed by the specialists in terms of pair wise relationships using linguistic assessments. For this, a five-level scale ( 0 - no influence, and 4 - very high influence) is defined in the Table II. Hence the direct-relation is made by taking the average of all grey direct-relation matrices, and given as:

$$
y=\left(\sum_{i=1}^{t} Y_{t}\right) / T
$$

Step3: Formulate normalized direct-relation matrix " $D$ ” via expressions $(2)-(4)$

$$
\otimes x=[\underline{x}, \bar{x}]=\frac{1}{\max _{1 \leq i \leq n} \sum_{j=1}^{n} \otimes Y i j}, i, j=1,2, \ldots n
$$

$$
D=\otimes x . . Y
$$

$$
\otimes d i j=[\underline{x} . \underline{y i j}, \bar{x} \cdot \overline{y i j}]
$$

Step4: Formulate total relation matrix "R" for the factors using Equation (5)

$$
R=D(I-D)^{-1}
$$

Where I is Unit matrix.

Step5: Find causal factors.

$\otimes Z i$ represents the sum of rows and $\otimes C j$ the sum of

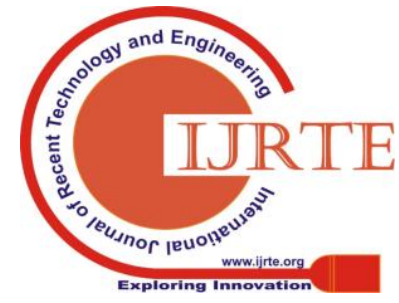


columns. Casual factor is calculated by using Equations (6) and (7).

$\otimes Z i=\sum_{i=1}^{n} S i \forall i$

(6)

$\otimes C j=\sum_{i=1}^{n} \otimes k i j \forall j$

Step6: Formulate the cause and effect diagram. Cause and effect diagram is obtained by utilizing the data containing $(\otimes \mathrm{Zi})$, prominence $(\otimes \mathrm{Mi})$ and net effect $(\otimes \mathrm{Ni})$ for the factors in CSR issues in supply chain management implementation using equations (8) and (9).

$$
\begin{aligned}
& \otimes M i=\{\otimes Z i+\otimes C j \mid i=j\} \\
& \otimes N i=\{\otimes Z i+\otimes C j \mid i=j\}
\end{aligned}
$$

Based on the cause or effect category, examine the identified factors associated to effective implementation of CSR activities.

We handed over 19 factors for expert's feedback. Specialists were asked to include or erase any factor they understood was critical/not essential. They accepted the writing based 19 factors and did not alter it either way. Thus, all 19 factors related to CSR in SCM implementation were chosen. After deciding the factors, professionals were asked to assess the direct relationship among the factors by means of a linguistic scale. (Table II). Table III and IV shows the Grey relationship matrices for the identified factors.

Table- II: Linguistic scale

\begin{tabular}{|c|l|l|}
\hline S.No & Linguistics assessment & Related grey scales \\
\hline 0 & No Influence & {$[0,0]$} \\
\hline 1 & Very Low Influence & {$[0,1]$} \\
\hline 2 & Low Influence & {$[1,2]$} \\
\hline 3 & High Influence & {$[2,3]$} \\
\hline 4 & Very High Influence & {$[3,4]$} \\
\hline
\end{tabular}

Table V shows the average grey relation matrix Y which was formed by using Equation (1). Next, by using Equations (2), (3) and (4), Normalized direct-relation matrix (D) was made and is shown in table VI. Next total relation matrix $\mathrm{R}$ is arrived by using Equation (5) and is given in table VII. Let $\otimes Z i$ denotes the summation of rows for $19 \times 1$ matrix, which is given in Equation (6). It shows the net effects given by factor $\mathrm{i}$ to other factors. $\otimes C j$ denotes the summation of columns for 1 x 19 matrix, which is given in Equation (7). It shows the net effects received by factor $\mathrm{j}$ from other factors. Equation (8) and (9) shows the calculation of prominence $(\otimes M i$ and net effects $\otimes N i$ ). If $\otimes N i$ is positive value, which means the factor is a net cause. If $\otimes N i$ is negative value, then the factor is a net effect.

\section{RESULTS AND DISCUSSION}

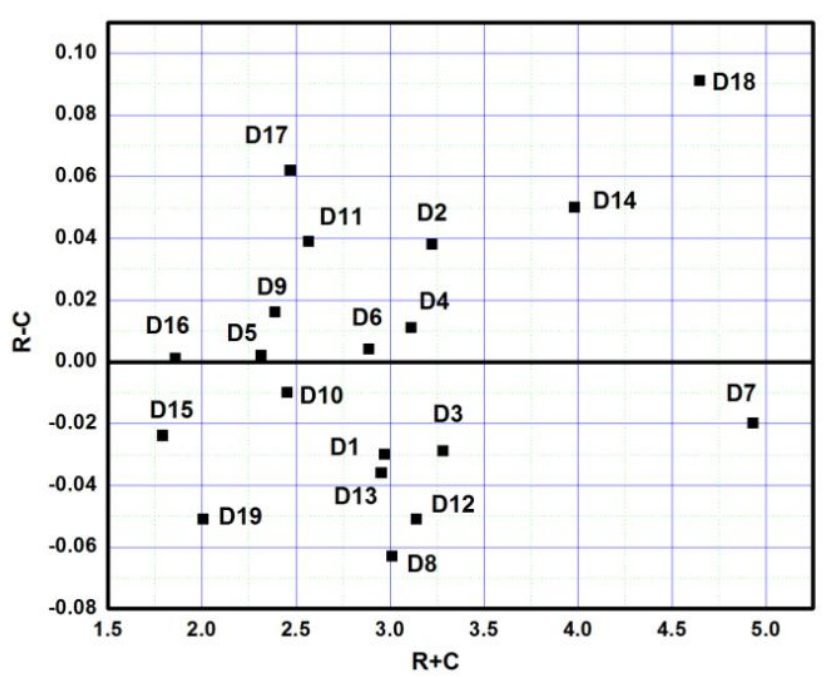

Fig.3. Causal relationship among the identified factors to implement CSR in SCM (for lower values)

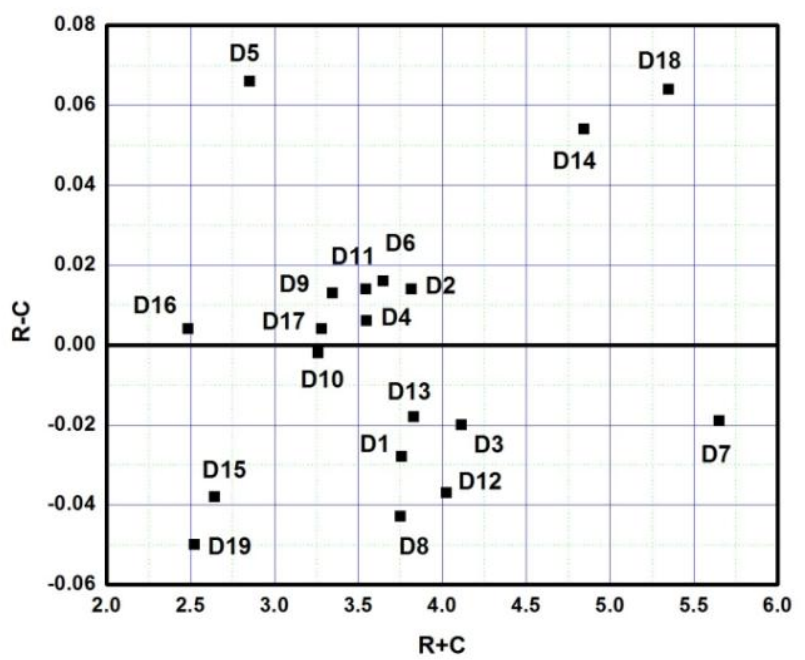

Fig.4 Causal relationship among the identified factors to implement CSR in SCM (for upper values).

Table VI represents the cause and effect category based on the $\mathrm{R}+\mathrm{C}$ data set. The order of importance is given as: D7-D18-D14-D3-D2-D12-D4-D8-D1-D13-D6-D11-D17-D 10-D9-D5-D19-D16-D15. In addition to that, ten factors D2, D4, D5, D6, D9, D11, D14, D16, D17, and D18 are classified as cause group factors based on the R-C score. Remaining nine factors D1, D3, D7, D8, D10, D12, D13, D15, and D19 are classified as effect group factors based on their respective $\mathrm{R}-\mathrm{C}$ data set value. Research findings were discussed with specialists to comprehend CSR problems from an industrial and business context; the details are given below.

\section{A. Influencing Factors}

Influencing factors are important one in the implementation of CSR initiatives which is critical and need work on it. "Industrial Relations" (D18) is the maximum R-C Score. This implies that Industrial Relations need to keep up with people effectively for CSR implementation. Thus, Industry personnel should outline strategies to energize CSR activities at all levels of the supply chain process. Women Empowerment (D17) is the second maximum score factor in (R-C) column which reasonably impacts other factors. Providing equal opportunities for women to

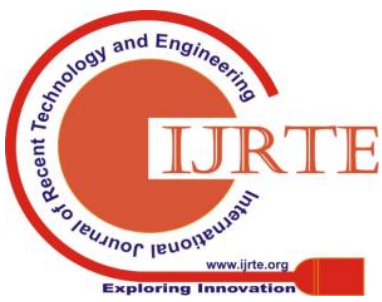


contribute completely in economic lives in all fields is needed to strengthen the economies. The third highest factor in $(\mathrm{R}-\mathrm{C})$ score is Corporate Governance (D14) shows it's important in the supply chain management system for the improvement of CSR implementation. It describes the problems in balancing organization's stakeholders, shareholders, customers, suppliers, government bodies, management, and regulators interest. Fourth maximum R-C score is Discrimination (D11) in the work place. The supplier should not discriminate on the basis of race, color, sex, language, disability, age, health status, and religion, political or other opinions. Suppliers have to ensure a work environment free from any form of harassment, especially sexual harassment. Other influencing factors are ranked Underage/Child labour (D2), Community (D9), Pollution (D4), Feminist Labour Issues (D6), Energy Conservation (D5), and Disaster relief (D16) respectively according to their scores.

\section{B. Influenced Factors}

Factors in the effect group also arranged like cause group. It also makes an important contribution on the system. In that, 'Environmental Degradation' (D8) is the maximum effect factor which is important factor for sustainable supply chain management to comply with the environmental issues by the suppliers and manufacturers generating hazardous wastes. The other influenced factors are Support Education and Healthcare (D19), Fair business (D12), Worker Health (D13), Human rights Issue (D1), Long working hours (D3), Poverty (D15), Organizational legal responsibilities (D7), and Unfair composition (D10). Cause factors which were suggested in this paper will help advance an extensive comprehension of CSR implementation and its benefits. Besides, managers are advised to attention on cause group factors like Industrial relations, Women's Empowerment, Corporate governance, Discrimination and Underage labor to enhance CSR initiatives success rate in supply chain management.

\section{Research Implications}

This paper allows suppliers, manufacturers, wholesalers, retailers, distributors, industry specialists and consumers to find and assess factors allied to CSR adoption. Implications of this research are given below:

Industry relations with public for implementation of CSR: It is significant to have smooth industrial relations in terms of social service, helping people, providing facilities for rural areas to implement CSR activities. Industry relations with the public will inspire CSR activities and increase supply chain management trends.

Corporate governance to balance CSR and SCM: It helps balance the interests of suppliers, stakeholders, management, customers, government and community between CSR activities and supply chain management activities. This enables an organization to standardize procedures, practices and methods which can be correctly absorbed and measured. Providing equal opportunities to women for CSR implementation: This work ensures equal opportunities for women in CSR implementation. To improve women's empowerment, seminar sessions may be arranged. Government/Organization can initiate equal opportunities in human development areas like education and healthcare, provide opportunities for women in decision making roles, increase women's personal security and reduce violence against women.

Eliminate Discrimination in the workplace: This work helps to eliminate discrimination in the workplace through equal pay for equal work without considerations of sex, community, language, religion, age, health status, etc... Organizations need to provide a work environment free from any form of harassment and ensure equal promotion and termination based on work done.

\section{CONCLUSION, LIMITATIONS, AND FUTURE WORK}

CSR is considered a most critical activity in supply chain management. In such a scenario, this research endeavors to address and comprehend issues faced in CSR implementation in supply chain management. In view of conceptual improvement, this work is an exercise to analyze factors to CSR implementation. A structural model is proposed to analyze CSR implementation factors. Eminently, nineteen factors identified through CSR activities are highlighted by using various literature review and experts' opinions from the industries. To determine the causal-effect relations among the factors, GREY-DEMATEL method is used. From the causal and effect diagram, the factors D2, D4, D5, D6, D9, D11, D14, D16, D17, and D18 are belonging to cause group and they require attention to attain the preferred objective. Remaining nine factors, D1, D3, D7, D8, D10, D12, D13, D15, and D19 are belonging to effect group and would improve CSR activities in supply chain management. Cause group factors are crucial and important one and have direct impact on the system. Therefore, it is significant that major attention will be given to the cause group factors. Effect group factors are driven by building effort on cause factors to obtain optimistic results in terms of the effect group. Human Rights issues, Long Working hours, Organizational legal responsibilities, Environmental Degradation, Unfair Composition, Fair business, Worker Health, Poverty and Supporting Education and Healthcare are vital factors. According to managerial point of view, focusing on cause group factors stabilizes the effect group factors through results concerning CSR execution. This work recommends nineteen factors in CSR implementation. To identify the CSR factors will be a challenge one for the future researchers. The GREY-DEMATEL method utilizes specialist's inputs, it is recommended to undertake the strategy deliberately. Other MCDM tools like ANP, TOPSIS, etc... can be used to analyze the identified factors. This research can be extended for other industrial sectors also. It should be remembered that specialists' assessments may vary according to their skill levels and the working domain.

\section{REFERENCES}

1. V.Baskaran, S.Nachiappan and S.Rahman, "Supplier assessment based on corporate social responsibility criteria in Indian automotive and textile industry sectors," International Journal of Sustainable Engineering, vol:4(4), 2011, pp.359-369.

2. K.Govindan, D.Kannan, and K.M.Shankar,"Evaluating the drivers of corporate social responsibility in the mining industry with multi-criteria approach: A multi-stakeholder perspective," Journal of cleaner production, vol:84, 2014, pp.214-232.

3.K.Govindan, M.Kaliyan, D.Kannan, and A.N.Haq,"Barriers analysis for green supply chain management implementation in Indian industries using analytic hierarchy process," International Journal of Production Economics, vol:147, 2014, pp.555-568.

4. K.Govindan, S.Rajendran, J.Sarkis, and P.Murugesan, "Multi criteria decision making approaches for green supplier evaluation and selection: a literature 
review," Journal of Cleaner Production, vol:98, 2015, pp.66-83.

5. P.Jia, K.Govindan and D.Kannan, "Identification and evaluation of influential criteria for the selection of an environmental shipping carrier using DEMATEL: a case from India," International Journal of Shipping and Transport Logistics, vol:7(6), 2015, pp.719-741.

6. V.S.Kouikoglou, Y.A.Phillis, "Application of a fuzzy hierarchical model to the assessment of corporate social and environmental sustainability. Corporate Social Responsibility and Environmental Management," vol:18(4), 2011, pp.209-219.

7. Y.Li, and K.Mathiyazhagan, "Application of DEMATEL approach to identify the influential indicators towards sustainable supply chain adoption in the auto components manufacturing sector," Journal of Cleaner Production, vol:172, 2018, pp.2931-2941.

8. S.Luthra, K.Govindan and S.K.Mangla,"Structural model for sustainable consumption and production adoption-A grey-DEMATEL based approach," Resources, Conservation and Recycling, vol:125, 2017, pp.198-207.

9. K.Mathiyazhagan, K.Govindan, A.NoorulHaq, and Y.Geng,“An ISM approach for the barrier analysis in implementing green supply chain management," Journal of Cleaner Production, vol:47, 2013, pp. 283-297.

10.S.Rajak, and S.Vinodh,"Application of fuzzy logic for social sustainability performance evaluation: a case study of an Indian automotive component manufacturing organization," Journal of Cleaner Production, vol:108, 2015, pp.1184-1192.

11. S.Seuring, and M.Müller "From a literature review to a conceptual framework for sustainable supply chain management," Journal of cleaner production, vol:16(15), 2008, pp.1699-1710.

12. S.Vinodh, T.S.Balagi, and A.Patil, "A hybrid MCDM approach for agile concept selection using fuzzy DEMATEL, fuzzy ANP and fuzzy TOPSIS," The International Journal of Advanced Manufacturing Technology,vol: 83(9-12), 2016, pp.1979-1987

\section{AUTHORS PROFILE}

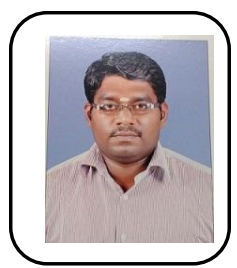

M.Ramaganesh obtained his Bachelor of Engineering in Mechanical Engineering from Arulmigu Kalasalingam College of Engineering, India in 2008. He finished his Master of Engineering in Industrial Engineering from Thiagarajar College of Engineering, India in 2015. He is currently taking up Doctor of Engineering with specialization in Industrial Engineering from Kalasalingam Academy of Research and Education, India. He is the member of Indian Society for Technical Education. His research interest includes Sustainability, Supply Chain Management, Environmental Management System and Corporate Social Responsibility.

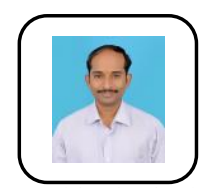

Dr.S.Bathrinath is an Associate Professor in the Department of Mechanical Engineering, Kalasalingam Academy of Research and Education, Krishnankoil, Tamilnadu, India. His current area of research includes multi-criteria decision making, scheduling \& optimization, soft computing and Artificial intelligence. He has published a number of papers in journal of national/international repute and presented a number of papers in various conferences/symposia in India and abroad. He is presently guiding a number of master/doctoral research scholars. Dr.S.Bathrinath is the corresponding author and can be contacted at: bathri@gmail.com

\section{ANNEXURE}

Table-III: Direct-Relation Matrix by Expert1 for the identified factors 


\begin{tabular}{|c|c|c|c|c|c|c|c|c|c|c|c|c|c|c|c|c|c|c|c|}
\hline & $D 1$ & D2 & D3 & D4 & D5 & D6 & D7 & D8 & D9 & $D 10$ & $D 11$ & $D 12$ & $D 13$ & D14 & D15 & $D 16$ & $D 17$ & $D 18$ & $D 19$ \\
\hline$D 1$ & $\begin{array}{l}{[0,} \\
0]\end{array}$ & {$[3,4$} & $\begin{array}{l}{[2,3} \\
]\end{array}$ & $\begin{array}{l}{[0,0} \\
]\end{array}$ & $\begin{array}{l}{[0,0} \\
]\end{array}$ & $\begin{array}{l}{[3,4} \\
]\end{array}$ & $\begin{array}{l}{[1,2} \\
]\end{array}$ & $\begin{array}{l}{[0,0} \\
]\end{array}$ & ]$^{[1,2}$ & $\begin{array}{l}{[2,3} \\
]\end{array}$ & $\begin{array}{l}{[2,3} \\
]\end{array}$ & $\begin{array}{l}{[1,2} \\
]\end{array}$ & $\begin{array}{l}{[2,3} \\
]\end{array}$ & $\begin{array}{l}{[1,2} \\
]\end{array}$ & $\begin{array}{l}{[0,1} \\
]\end{array}$ & $\begin{array}{l}{[0,0} \\
]\end{array}$ & $\begin{array}{l}{[3,4} \\
]\end{array}$ & $\begin{array}{l}{[2,3} \\
]\end{array}$ & {$[1,2]$} \\
\hline$D 2$ & $\begin{array}{l}3, \\
4] \\
\end{array}$ & $\begin{array}{l}{[0,0} \\
]\end{array}$ & $\begin{array}{l}{[3,4} \\
]\end{array}$ & $\begin{array}{l}{[0,0} \\
]\end{array}$ & $\begin{array}{l}{[0,0} \\
]\end{array}$ & $\begin{array}{l}{[0,0} \\
]\end{array}$ & ]$^{[3,4}$ & $\begin{array}{l}{[0,0} \\
]]\end{array}$ & $\begin{array}{l}{[2,3} \\
]\end{array}$ & {$[2,3$} & $\begin{array}{l}{[1,2} \\
]\end{array}$ & $\begin{array}{l}{[0,0} \\
]\end{array}$ & ]$^{[3,4}$ & $\begin{array}{l}{[2,3} \\
]\end{array}$ & $\begin{array}{l}{[3,4} \\
]\end{array}$ & $\begin{array}{l}{[1,2} \\
]\end{array}$ & $\begin{array}{l}{[0,0} \\
]\end{array}$ & $\begin{array}{l}{[2,3} \\
]\end{array}$ & {$[2,3]$} \\
\hline$D 3$ & $\begin{array}{l}{[2,} \\
3]\end{array}$ & $\begin{array}{l}{[3,4} \\
]\end{array}$ & $\begin{array}{l}{[0,0} \\
]\end{array}$ & $\begin{array}{l}{[2,3} \\
]\end{array}$ & $\begin{array}{l}{[2,3} \\
]\end{array}$ & $\begin{array}{l}{[2,3} \\
]\end{array}$ & $\begin{array}{l}{[2,3} \\
]\end{array}$ & $\begin{array}{l}{[1,2} \\
]\end{array}$ & $\begin{array}{l}{[0,0} \\
]\end{array}$ & {$[0,1$} & {$[1,2$} & $\begin{array}{l}{[2,3} \\
]\end{array}$ & {$[2,3$} & $\begin{array}{l}{[2,3} \\
]\end{array}$ & {$[2,3$} & {$[0,0$} & {$[1,2$} & {$[2,3$} & {$[0,0]$} \\
\hline$D 4$ & $\begin{array}{l}{[0,} \\
0]\end{array}$ & $\begin{array}{l}{[0,0} \\
]\end{array}$ & $\begin{array}{l}{[2,3} \\
]\end{array}$ & $\begin{array}{l}{[0,0} \\
]\end{array}$ & $\begin{array}{l}{[2,3} \\
]\end{array}$ & $\begin{array}{l}{[0,0} \\
]\end{array}$ & ]$^{[3,4}$ & $\begin{array}{l}{[2,3} \\
]\end{array}$ & $\begin{array}{l}{[2,3} \\
]\end{array}$ & {$[0,0$} & $\begin{array}{l}{[0,0} \\
]\end{array}$ & $\begin{array}{l}{[2,3} \\
]\end{array}$ & $\begin{array}{l}{[3,4} \\
]\end{array}$ & $\begin{array}{l}{[3,4} \\
]\end{array}$ & $\begin{array}{l}{[0,0} \\
]\end{array}$ & $\begin{array}{l}{[2,3} \\
]\end{array}$ & $\begin{array}{l}{[0,0} \\
]\end{array}$ & $\begin{array}{l}{[3,4} \\
]\end{array}$ & {$[0,0]$} \\
\hline D5 & $\begin{array}{l}{[0,} \\
0]\end{array}$ & $\begin{array}{l}{[0,0} \\
]\end{array}$ & $\begin{array}{l}{[2,3} \\
]\end{array}$ & {$[2,3$} & $\begin{array}{l}{[0,0} \\
]\end{array}$ & $\begin{array}{l}{[0,0} \\
]\end{array}$ & {$[2,3$} & {$[2,3$} & {$[1,2$} & {$[0,0$} & {$[0,0$} & {$[2,3$} & $\begin{array}{l}{[1,2} \\
]\end{array}$ & {$[2,3$} & {$[0,0$} & {$[0,0$} & $\begin{array}{l}{[0,0} \\
]\end{array}$ & $\begin{array}{l}{[3,4} \\
]\end{array}$ & {$[0,0]$} \\
\hline D6 & $\begin{array}{l}\text { [3, } \\
4]\end{array}$ & $\begin{array}{l}{[0,0} \\
]\end{array}$ & $\begin{array}{l}{[2,3} \\
]\end{array}$ & $\begin{array}{l}{[0,0} \\
]\end{array}$ & $\begin{array}{l}{[0,0} \\
]\end{array}$ & $\begin{array}{l}{[0,0} \\
]\end{array}$ & $\begin{array}{l}{[3,4} \\
]\end{array}$ & $\begin{array}{l}{[1,2} \\
]\end{array}$ & $\begin{array}{l}{[1,2} \\
]\end{array}$ & $\begin{array}{l}{[0,1} \\
]\end{array}$ & {$[1,2$} & $\begin{array}{l}{[2,3} \\
]\end{array}$ & $\begin{array}{l}{[1,2} \\
]\end{array}$ & $\begin{array}{l}{[2,3} \\
]\end{array}$ & {$[2,3$} & {$[0,0$} & $\begin{array}{l}{[2,3} \\
]\end{array}$ & $\begin{array}{l}{[2,3} \\
]\end{array}$ & {$[0,0]$} \\
\hline$D 7$ & $\begin{array}{l}{[1,} \\
2]\end{array}$ & $\begin{array}{l}{[3,4} \\
]\end{array}$ & $\begin{array}{l}{[2,3} \\
]\end{array}$ & $\begin{array}{l}{[3,4} \\
]\end{array}$ & $\begin{array}{l}{[2,3} \\
]\end{array}$ & $\begin{array}{l}{[3,4} \\
]\end{array}$ & $\begin{array}{l}{[0,0} \\
]\end{array}$ & $\begin{array}{l}{[3,4} \\
]\end{array}$ & $\begin{array}{l}{[2,3} \\
]\end{array}$ & $\begin{array}{l}{[3,4} \\
]\end{array}$ & $\begin{array}{l}{[2,3} \\
]\end{array}$ & $\begin{array}{l}{[3,4} \\
]\end{array}$ & $\begin{array}{l}{[2,3} \\
]\end{array}$ & $\begin{array}{l}{[3,4} \\
]\end{array}$ & $\begin{array}{l}{[0,1} \\
]\end{array}$ & $\begin{array}{l}{[2,3} \\
]\end{array}$ & $\begin{array}{l}{[2,3} \\
]\end{array}$ & $\begin{array}{l}{[3,4} \\
]\end{array}$ & {$[2,3]$} \\
\hline$D 8$ & $\begin{array}{l}{[0,} \\
0]\end{array}$ & $\begin{array}{l}{[0,0} \\
]\end{array}$ & $\begin{array}{l}{[1,2} \\
]\end{array}$ & $\begin{array}{l}{[2,3} \\
]\end{array}$ & $\begin{array}{l}{[2,3} \\
]\end{array}$ & $\begin{array}{l}{[1,2} \\
]\end{array}$ & {$[3,4$} & $\begin{array}{l}{[0,0} \\
]\end{array}$ & $\begin{array}{l}{[1,2} \\
]\end{array}$ & $\begin{array}{l}{[0,0} \\
]\end{array}$ & $\begin{array}{l}{[0,1} \\
]\end{array}$ & $\begin{array}{l}{[2,3} \\
]\end{array}$ & $\begin{array}{l}{[2,3} \\
]\end{array}$ & $\begin{array}{l}{[3,4} \\
]\end{array}$ & $\begin{array}{l}{[1,2} \\
]\end{array}$ & $\begin{array}{l}{[2,3} \\
]\end{array}$ & $\begin{array}{l}{[1,2} \\
]\end{array}$ & $\begin{array}{l}{[3,4} \\
]\end{array}$ & {$[0,0]$} \\
\hline$D 9$ & $\begin{array}{l}1, \\
2]\end{array}$ & $\begin{array}{l}{[2,3} \\
]\end{array}$ & $\begin{array}{l}{[0,0} \\
]\end{array}$ & $\begin{array}{l}{[2,3} \\
]\end{array}$ & $\begin{array}{l}{[1,2} \\
]\end{array}$ & ]$^{[1,2}$ & $\begin{array}{l}{[2,3} \\
]\end{array}$ & $\begin{array}{l}{[1,2} \\
]\end{array}$ & $\begin{array}{l}{[0,0} \\
]\end{array}$ & $\begin{array}{l}{[1,2} \\
]\end{array}$ & $\begin{array}{l}{[3,4} \\
]\end{array}$ & $\begin{array}{l}{[0,1} \\
]\end{array}$ & $\begin{array}{l}{[0,0} \\
]\end{array}$ & $\begin{array}{l}{[1,2} \\
]\end{array}$ & $\begin{array}{l}{[1,2} \\
]\end{array}$ & $\begin{array}{l}{[0,0} \\
]\end{array}$ & $\begin{array}{l}{[0,1} \\
]\end{array}$ & $\begin{array}{l}{[2,3} \\
]\end{array}$ & {$[1,2]$} \\
\hline$D 10$ & $\begin{array}{l}{[2,} \\
3]\end{array}$ & $\begin{array}{l}{[2,3} \\
]\end{array}$ & $\begin{array}{l}{[0,1} \\
]\end{array}$ & $\begin{array}{l}{[0,0} \\
]\end{array}$ & $\begin{array}{l}{[0,0} \\
]\end{array}$ & $\begin{array}{l}{[0,1} \\
]\end{array}$ & $\begin{array}{l}{[3,4} \\
]\end{array}$ & $\begin{array}{l}{[0,0} \\
]\end{array}$ & $\begin{array}{l}{[1,2} \\
]\end{array}$ & {$[0,0$} & $\begin{array}{l}{[3,4} \\
]\end{array}$ & $\begin{array}{l}{[1,2} \\
]\end{array}$ & $\begin{array}{l}{[1,2} \\
]\end{array}$ & {$[2,3$} & {$[2,3$} & {$[0,0$} & $\begin{array}{l}{[0,1} \\
]\end{array}$ & $\begin{array}{l}{[2,3} \\
]\end{array}$ & {$[0,0]$} \\
\hline$D 11$ & $\begin{array}{l}{[2,} \\
3]\end{array}$ & $\begin{array}{l}{[1,2} \\
]\end{array}$ & $\begin{array}{l}{[1,2} \\
]\end{array}$ & $\begin{array}{l}{[0,0} \\
]\end{array}$ & $\begin{array}{l}{[0,0} \\
]\end{array}$ & $\begin{array}{l}{[1,2} \\
]\end{array}$ & $\begin{array}{l}{[2,3} \\
]\end{array}$ & $\begin{array}{l}{[0,1} \\
]\end{array}$ & $\begin{array}{l}{[3,4} \\
]\end{array}$ & $\begin{array}{l}{[3,4} \\
]^{2}\end{array}$ & $\begin{array}{l}{[0,0} \\
]\end{array}$ & $\begin{array}{l}{[0,1} \\
]\end{array}$ & $\begin{array}{l}{[1,2} \\
]\end{array}$ & $\begin{array}{l}{[2,3} \\
]\end{array}$ & $\begin{array}{l}{[1,2} \\
]\end{array}$ & $\begin{array}{l}{[1,2} \\
]\end{array}$ & $\begin{array}{l}{[1,2} \\
]\end{array}$ & $\begin{array}{l}{[2,3} \\
]\end{array}$ & {$[0,0]$} \\
\hline$D 12$ & $\begin{array}{l}{[1,} \\
2]\end{array}$ & $\begin{array}{l}{[0,0} \\
]\end{array}$ & $\begin{array}{l}{[2,3} \\
]\end{array}$ & $\begin{array}{l}{[2,3} \\
]\end{array}$ & $\begin{array}{l}{[2,3} \\
]\end{array}$ & $\begin{array}{l}{[2,3} \\
]\end{array}$ & $\begin{array}{l}{[3,4} \\
]\end{array}$ & $\begin{array}{l}{[2,3} \\
]\end{array}$ & $\begin{array}{l}{[0,1} \\
]\end{array}$ & $\begin{array}{l}{[1,2} \\
]\end{array}$ & $\begin{array}{l}{[0,1} \\
]\end{array}$ & $\begin{array}{l}{[0,0} \\
]\end{array}$ & $\begin{array}{l}{[0,1} \\
]\end{array}$ & $\begin{array}{l}{[2,3} \\
]\end{array}$ & $\begin{array}{l}{[0,0} \\
]\end{array}$ & $\begin{array}{l}{[0,1} \\
]\end{array}$ & $\begin{array}{l}{[2,3} \\
]\end{array}$ & $\begin{array}{l}{[3,4} \\
]\end{array}$ & {$[2,3]$} \\
\hline D13 & $\begin{array}{l}{[2,} \\
3]\end{array}$ & $\begin{array}{l}{[3,4} \\
]\end{array}$ & $\begin{array}{l}{[2,3} \\
]\end{array}$ & {$[3,4$} & {$[1,2$} & $\begin{array}{l}{[1,2} \\
]\end{array}$ & {$[2,3$} & {$[2,3$} & $\begin{array}{l}{[0,0} \\
]\end{array}$ & {$[1,2$} & {$[1,2$} & {$[0,1$} & {$[0,0$} & {$[1,2$} & {$[2,3$} & {$[2,3$} & {$[0,0$} & $\begin{array}{l}{[1,2} \\
]\end{array}$ & {$[0,0]$} \\
\hline$D 14$ & $\begin{array}{l}{[1,} \\
2]\end{array}$ & $\begin{array}{l}{[2,3} \\
]\end{array}$ & $\begin{array}{l}{[2,3} \\
]\end{array}$ & $\begin{array}{l}{[3,4} \\
]\end{array}$ & $\begin{array}{l}{[2,3} \\
]\end{array}$ & $\begin{array}{l}{[2,3} \\
]\end{array}$ & $\begin{array}{l}{[3,4} \\
]\end{array}$ & $\begin{array}{l}{[3,4} \\
]\end{array}$ & $\begin{array}{l}{[1,2} \\
]\end{array}$ & $\begin{array}{l}{[2,3} \\
]\end{array}$ & $\begin{array}{l}{[2,3} \\
]\end{array}$ & $\begin{array}{l}{[2,3} \\
]\end{array}$ & $\begin{array}{l}{[1,2} \\
]\end{array}$ & $\begin{array}{l}{[0,0} \\
]\end{array}$ & $\begin{array}{l}{[0,1} \\
]\end{array}$ & $\begin{array}{l}{[1,2} \\
]\end{array}$ & $\begin{array}{l}{[2,3} \\
]\end{array}$ & $\begin{array}{l}{[2,3} \\
]\end{array}$ & {$[2,3]$} \\
\hline$D 15$ & $\begin{array}{l}{[0,} \\
1]\end{array}$ & $\begin{array}{l}{[3,4} \\
]\end{array}$ & $\begin{array}{l}{[2,3} \\
]\end{array}$ & $\begin{array}{l}{[0,0} \\
]\end{array}$ & $\begin{array}{l}{[0,0} \\
]\end{array}$ & $\begin{array}{l}{[2,3} \\
]\end{array}$ & $\begin{array}{l}{[0,1} \\
]\end{array}$ & $\begin{array}{l}{[1,2} \\
]\end{array}$ & $\begin{array}{l}{[1,2} \\
]\end{array}$ & $\begin{array}{l}{[2,3} \\
]\end{array}$ & $\begin{array}{l}{[1,2} \\
]\end{array}$ & $\begin{array}{l}{[0,0} \\
]\end{array}$ & $\begin{array}{l}{[2,3} \\
]\end{array}$ & $\begin{array}{l}{[0,1} \\
]\end{array}$ & $\begin{array}{l}{[0,0} \\
]\end{array}$ & $\begin{array}{l}{[0,0} \\
]\end{array}$ & $\begin{array}{l}{[1,2} \\
]\end{array}$ & $\begin{array}{l}{[0,0} \\
]\end{array}$ & {$[0,0]$} \\
\hline$D 16$ & $\begin{array}{l}{[0,} \\
0]\end{array}$ & $\begin{array}{l}{[1,2} \\
]\end{array}$ & $\begin{array}{l}{[0,0} \\
]\end{array}$ & $\begin{array}{l}{[2,3} \\
]\end{array}$ & $\begin{array}{l}{[0,0} \\
]\end{array}$ & $\begin{array}{l}{[0,0} \\
]\end{array}$ & $\begin{array}{l}{[2,3} \\
]\end{array}$ & $\begin{array}{l}{[2,3} \\
]\end{array}$ & $\begin{array}{l}{[0,0} \\
]\end{array}$ & $\begin{array}{l}{[0,0} \\
]\end{array}$ & $\begin{array}{l}{[1,2} \\
]\end{array}$ & $\begin{array}{l}{[0,1} \\
]\end{array}$ & $\begin{array}{l}{[2,3} \\
]\end{array}$ & $\begin{array}{l}{[1,2} \\
]\end{array}$ & $\begin{array}{l}{[0,0} \\
]\end{array}$ & $\begin{array}{l}{[0,0} \\
]\end{array}$ & $\begin{array}{l}{[0,0} \\
]\end{array}$ & $\begin{array}{l}{[2,3} \\
]\end{array}$ & {$[1,2]$} \\
\hline$D 17$ & $\begin{array}{l}\text { [3, } \\
4]\end{array}$ & $\begin{array}{l}{[0,0} \\
]\end{array}$ & $\begin{array}{l}{[1,2} \\
]\end{array}$ & $\begin{array}{l}{[0,0} \\
]\end{array}$ & $\begin{array}{l}{[0,0} \\
]\end{array}$ & $\begin{array}{l}{[2,3} \\
]\end{array}$ & $\begin{array}{l}{[2,3} \\
]\end{array}$ & $\begin{array}{l}{[1,2} \\
]\end{array}$ & $\begin{array}{l}{[0,1} \\
]\end{array}$ & $\begin{array}{l}{[0,1} \\
]\end{array}$ & $\begin{array}{l}{[1,2} \\
]\end{array}$ & $\begin{array}{l}{[2,3} \\
]\end{array}$ & $\begin{array}{l}{[0,0} \\
]\end{array}$ & $\begin{array}{l}{[2,3} \\
]\end{array}$ & $\begin{array}{l}{[1,2} \\
]\end{array}$ & $\begin{array}{l}{[0,0} \\
]\end{array}$ & $\begin{array}{l}{[0,0} \\
]\end{array}$ & $\begin{array}{l}{[2,3} \\
]\end{array}$ & {$[1,2]$} \\
\hline D18 & $\begin{array}{l}{[2,} \\
3]\end{array}$ & $\begin{array}{l}{[2,3} \\
]\end{array}$ & $\begin{array}{l}{[2,3} \\
]\end{array}$ & $\begin{array}{l}{[3,4} \\
]\end{array}$ & $\begin{array}{l}{[3,4} \\
]\end{array}$ & $\begin{array}{l}{[2,3} \\
]\end{array}$ & $\begin{array}{l}{[3,4} \\
]\end{array}$ & $\begin{array}{l}{[3,4} \\
]\end{array}$ & $\begin{array}{l}{[2,3} \\
]\end{array}$ & $\begin{array}{l}{[2,3} \\
]\end{array}$ & $\begin{array}{l}{[2,3} \\
]\end{array}$ & $\begin{array}{l}{[3,4} \\
]\end{array}$ & $\begin{array}{l}{[1,2} \\
]\end{array}$ & {$\left[\begin{array}{l}{[2,3} \\
]\end{array}\right.$} & $\begin{array}{l}{[0,0} \\
]\end{array}$ & $\begin{array}{l}{[2,3} \\
]\end{array}$ & $\begin{array}{l}{[2,3} \\
]\end{array}$ & $\begin{array}{l}{[0,0} \\
]\end{array}$ & {$[3,4]$} \\
\hline$D 19$ & $\begin{array}{l}{[1,} \\
2]\end{array}$ & $\begin{array}{l}{[2,3} \\
]\end{array}$ & $\begin{array}{l}{[0,0} \\
]\end{array}$ & $\begin{array}{l}{[0,0} \\
]\end{array}$ & {$[0,0$} & $\begin{array}{l}{[0,0} \\
]\end{array}$ & $\begin{array}{l}{[2,3} \\
]\end{array}$ & $\begin{array}{l}{[0,0} \\
]\end{array}$ & $\begin{array}{l}{[1,2} \\
]\end{array}$ & $\begin{array}{l}{[0,0} \\
]\end{array}$ & $\begin{array}{l}{[0,0} \\
]\end{array}$ & $\begin{array}{l}{[2,3} \\
]\end{array}$ & $\begin{array}{l}{[0,0} \\
]^{2}\end{array}$ & $\begin{array}{l}{[2,3} \\
]\end{array}$ & $\begin{array}{l}{[0,0} \\
]^{2}\end{array}$ & $\begin{array}{l}{[1,2} \\
]\end{array}$ & $\begin{array}{l}{[1,2} \\
]\end{array}$ & $\begin{array}{l}{[3,4} \\
]\end{array}$ & {$[0,0]$} \\
\hline
\end{tabular}

Table-IV: Direct-Relation Matrix by Expert2 for the identified factors

\begin{tabular}{|c|c|c|c|c|c|c|c|c|c|c|c|c|c|c|c|c|c|c|c|}
\hline & D1 & D2 & D3 & $D 4$ & D5 & D6 & D7 & D8 & $D 9$ & $D 10$ & D11 & $D 12$ & D13 & D14 & D15 & D16 & D17 & $D 18$ & $D 19$ \\
\hline$D 1$ & $\begin{array}{l}{[0,0} \\
]\end{array}$ & $\begin{array}{l}{[2,3} \\
]\end{array}$ & $\begin{array}{l}{[2,3} \\
]\end{array}$ & $\begin{array}{l}{[0,0} \\
]\end{array}$ & $\begin{array}{l}{[0,0} \\
]\end{array}$ & {$[3,4$} & ]$^{[1,2}$ & $\begin{array}{l}{[0,0} \\
]\end{array}$ & $\begin{array}{l}{[1,2} \\
]\end{array}$ & ]$^{[2,3}$ & $\begin{array}{l}{[1,2} \\
]\end{array}$ & ]$^{[2,3}$ & $\begin{array}{l}{[2,3} \\
]\end{array}$ & {$[1,2$} & {$[1,2$} & $\begin{array}{l}{[0,0} \\
]\end{array}$ & $\begin{array}{l}{[3,4} \\
]\end{array}$ & ]$^{[2,3}$ & {$[1,2$} \\
\hline$D 2$ & $\begin{array}{l}{[3,4} \\
]\end{array}$ & $\begin{array}{l}{[0,0} \\
]\end{array}$ & $\begin{array}{l}{[3,4} \\
]\end{array}$ & $\begin{array}{l}{[0,0} \\
]\end{array}$ & $\begin{array}{l}{[0,0} \\
]\end{array}$ & $\begin{array}{l}{[0,0} \\
]\end{array}$ & $\begin{array}{l}3,4 \\
]\end{array}$ & $\begin{array}{l}{[0,0} \\
]\end{array}$ & $\begin{array}{l}{[2,3} \\
]\end{array}$ & $\begin{array}{l}{[2,3} \\
]\end{array}$ & $\begin{array}{l}{[1,2} \\
]\end{array}$ & $\begin{array}{l}{[0,0} \\
]\end{array}$ & $\begin{array}{l}{[3,4} \\
]\end{array}$ & {$[2,3$} & $\begin{array}{l}{[3,4} \\
]\end{array}$ & ]$^{[1,2}$ & $\begin{array}{l}{[0,0} \\
]\end{array}$ & $\begin{array}{l}{[2,3} \\
]\end{array}$ & $\begin{array}{l}{[2,3} \\
]\end{array}$ \\
\hline D3 & $\begin{array}{l}{[2,3} \\
]\end{array}$ & $\begin{array}{l}{[3,4} \\
]\end{array}$ & $\begin{array}{l}{[0,0} \\
]\end{array}$ & $\begin{array}{l}{[2,3} \\
]\end{array}$ & $\begin{array}{l}{[2,3} \\
]\end{array}$ & $\begin{array}{l}{[2,3} \\
]\end{array}$ & $\begin{array}{l}{[2,3} \\
]\end{array}$ & $\begin{array}{l}{[1,2} \\
]\end{array}$ & $\begin{array}{l}{[0,0} \\
]\end{array}$ & ]$^{[0,1}$ & $\begin{array}{l}{[1,2} \\
]\end{array}$ & $\begin{array}{l}{[2,3} \\
]\end{array}$ & $\begin{array}{l}{[2,3} \\
]\end{array}$ & $\begin{array}{l}{[2,3} \\
]\end{array}$ & ]$^{[2,3}$ & $\begin{array}{l}{[0,0} \\
]\end{array}$ & $\begin{array}{l}{[1,2} \\
]\end{array}$ & $\begin{array}{l}{[2,3} \\
]\end{array}$ & $\begin{array}{l}{[0,0} \\
]\end{array}$ \\
\hline$D 4$ & $\begin{array}{l}{[0,0} \\
]\end{array}$ & $\begin{array}{l}{[0,0} \\
]\end{array}$ & $\begin{array}{l}{[2,3} \\
]\end{array}$ & $\begin{array}{l}{[0,0} \\
]\end{array}$ & $\begin{array}{l}{[2,3} \\
]\end{array}$ & $\begin{array}{l}{[0,0} \\
]\end{array}$ & $\begin{array}{l}{[3,4} \\
]\end{array}$ & $\begin{array}{l}{[2,3} \\
]\end{array}$ & $\begin{array}{l}{[2,3} \\
]\end{array}$ & $\begin{array}{l}{[0,0} \\
]\end{array}$ & $\begin{array}{l}{[0,0} \\
]\end{array}$ & $\begin{array}{l}{[2,3} \\
]\end{array}$ & $\begin{array}{l}{[3,4} \\
]\end{array}$ & $\begin{array}{l}{[3,4} \\
]\end{array}$ & $\begin{array}{l}{[0,0} \\
]\end{array}$ & $\begin{array}{l}{[2,3} \\
]\end{array}$ & $\begin{array}{l}{[0,1} \\
]\end{array}$ & $\begin{array}{l}{[3,4} \\
]\end{array}$ & $\begin{array}{l}{[0,0} \\
]\end{array}$ \\
\hline$D 5$ & $\begin{array}{l}{[0,0} \\
]\end{array}$ & $\begin{array}{l}{[0,1} \\
] \\
\end{array}$ & $\begin{array}{l}{[2,3} \\
]\end{array}$ & $\begin{array}{l}{[2,3} \\
]\end{array}$ & $\begin{array}{l}{[0,0} \\
]\end{array}$ & $\begin{array}{l}{[0,0} \\
]\end{array}$ & $\begin{array}{l}{[2,3} \\
]\end{array}$ & $\begin{array}{l}{[2,3} \\
]\end{array}$ & $\begin{array}{l}{[1,2} \\
]\end{array}$ & $\begin{array}{l}{[0,0} \\
]\end{array}$ & $\begin{array}{l}{[0,0} \\
]\end{array}$ & $\begin{array}{l}{[2,3} \\
]\end{array}$ & $\begin{array}{l}{[1,2} \\
]\end{array}$ & {$[2,3$} & $\begin{array}{l}{[0,0} \\
]\end{array}$ & $\begin{array}{l}{[0,0} \\
]\end{array}$ & $\begin{array}{l}{[0,1} \\
]\end{array}$ & $\begin{array}{l}{[3,4} \\
]\end{array}$ & $\begin{array}{l}{[0,0} \\
]\end{array}$ \\
\hline$D 6$ & $\begin{array}{l}{[3,4} \\
]\end{array}$ & $\begin{array}{l}{[0,1} \\
]\end{array}$ & $\begin{array}{l}{[2,3} \\
]\end{array}$ & $\begin{array}{l}{[0,0} \\
]\end{array}$ & $\begin{array}{l}{[0,0} \\
]\end{array}$ & $\begin{array}{l}{[0,0} \\
]\end{array}$ & $\begin{array}{l}{[3,4} \\
]\end{array}$ & $\begin{array}{l}{[1,2} \\
]\end{array}$ & $\begin{array}{l}{[1,2} \\
]\end{array}$ & {$[0,1$} & $\begin{array}{l}{[1,2} \\
]\end{array}$ & $\begin{array}{l}{[2,3} \\
]\end{array}$ & $\begin{array}{l}{[2,3} \\
]\end{array}$ & $\begin{array}{l}{[2,3} \\
]\end{array}$ & {$[2,3$} & {$[0,0$} & {$[2,3$} & {$[2,3$} & {$[0,0$} \\
\hline$D 7$ & $\begin{array}{l}{[2,3} \\
]\end{array}$ & $\begin{array}{l}{[3,4} \\
]\end{array}$ & $\begin{array}{l}{[2,3} \\
]\end{array}$ & $\begin{array}{l}{[3,4} \\
]\end{array}$ & $\begin{array}{l}{[2,3} \\
]\end{array}$ & $\begin{array}{l}{[3,4} \\
]\end{array}$ & $\begin{array}{l}{[0,0} \\
]\end{array}$ & $\begin{array}{l}{[3,4} \\
]\end{array}$ & $\begin{array}{l}{[2,3} \\
]\end{array}$ & $\begin{array}{l}{[3,4} \\
]\end{array}$ & $\begin{array}{l}{[2,3} \\
]\end{array}$ & $\begin{array}{l}{[3,4} \\
]\end{array}$ & $\begin{array}{l}{[2,3} \\
]\end{array}$ & $\begin{array}{l}{[3,4} \\
]\end{array}$ & ]$^{[0,1}$ & $\begin{array}{l}{[2,3} \\
]\end{array}$ & $\begin{array}{l}{[2,3} \\
]\end{array}$ & $\begin{array}{l}{[2,3} \\
]\end{array}$ & $\begin{array}{l}{[2,3} \\
]\end{array}$ \\
\hline$D 8$ & $\begin{array}{l}{[0,0} \\
]\end{array}$ & $\begin{array}{l}{[0,0} \\
]\end{array}$ & $\begin{array}{l}{[0,1} \\
]\end{array}$ & $\begin{array}{l}{[2,3} \\
]\end{array}$ & $\begin{array}{l}{[2,3} \\
]\end{array}$ & $\begin{array}{l}{[1,2} \\
]\end{array}$ & $\begin{array}{l}{[3,4} \\
]\end{array}$ & $\begin{array}{l}{[0,0} \\
]\end{array}$ & $\begin{array}{l}{[1,2} \\
]\end{array}$ & $\begin{array}{l}{[0,0} \\
]\end{array}$ & $\begin{array}{l}{[0,1} \\
]\end{array}$ & $\begin{array}{l}{[2,3} \\
]\end{array}$ & $\begin{array}{l}{[2,3} \\
]\end{array}$ & $\begin{array}{l}{[2,3} \\
]\end{array}$ & $\begin{array}{l}{[1,2} \\
]\end{array}$ & $\begin{array}{l}{[2,3} \\
]\end{array}$ & $\begin{array}{l}{[1,2} \\
]\end{array}$ & $\begin{array}{l}{[3,4} \\
]\end{array}$ & $\begin{array}{l}{[0,0} \\
]\end{array}$ \\
\hline$D^{9}$ & $\begin{array}{l}{[1,2} \\
]\end{array}$ & $\begin{array}{l}{[1,2} \\
]\end{array}$ & $\begin{array}{l}{[0,0} \\
]\end{array}$ & $\begin{array}{l}{[2,3} \\
]\end{array}$ & $\begin{array}{l}{[1,2} \\
]\end{array}$ & {$[1,2$} & $\begin{array}{l}{[3,4} \\
]\end{array}$ & $\begin{array}{l}{[1,2} \\
]\end{array}$ & $\begin{array}{l}{[0,0} \\
]\end{array}$ & $\begin{array}{l}{[1,2} \\
]\end{array}$ & $\begin{array}{l}{[3,4} \\
]\end{array}$ & $\begin{array}{l}{[0,1} \\
]\end{array}$ & $\begin{array}{l}{[0,0} \\
]\end{array}$ & $\begin{array}{l}{[1,2} \\
]\end{array}$ & {$[1,2$} & $\begin{array}{l}{[0,0} \\
]\end{array}$ & $\begin{array}{l}{[0,1} \\
]\end{array}$ & $\begin{array}{l}{[2,3} \\
]\end{array}$ & $\begin{array}{l}{[1,2} \\
]\end{array}$ \\
\hline $\begin{array}{l}D 1 \\
0 \\
\end{array}$ & $\begin{array}{l}{[2,3} \\
]\end{array}$ & $\begin{array}{l}{[2,3} \\
]\end{array}$ & $\begin{array}{l}{[1,2} \\
]\end{array}$ & $\begin{array}{l}{[0,0} \\
]\end{array}$ & $\begin{array}{l}{[0,0} \\
]\end{array}$ & $\begin{array}{l}{[0,1} \\
]\end{array}$ & $\begin{array}{l}{[2,3} \\
]\end{array}$ & $\begin{array}{l}{[0,0} \\
]\end{array}$ & {$[1,2$} & {$[0,0$} & $\begin{array}{l}{[3,4} \\
]\end{array}$ & {$[1,2$} & {$[1,2$} & {$[2,3$} & {$[2,3$} & $\begin{array}{l}{[0,0} \\
]\end{array}$ & {$[0,1$} & {$[2,3$} & {$[0,0$} \\
\hline $\begin{array}{l}D 1 \\
1 \\
\end{array}$ & $\begin{array}{l}{[2,3} \\
]\end{array}$ & $\begin{array}{l}{[1,2} \\
]\end{array}$ & $\begin{array}{l}{[1,2} \\
]\end{array}$ & $\begin{array}{l}{[0,0} \\
]\end{array}$ & $\begin{array}{l}{[0,0} \\
]\end{array}$ & $\begin{array}{l}{[2,3} \\
]\end{array}$ & $\begin{array}{l}{[2,3} \\
]\end{array}$ & $\begin{array}{l}{[0,1} \\
]\end{array}$ & $\begin{array}{l}{[3,4} \\
]\end{array}$ & $\begin{array}{l}{[3,4} \\
]\end{array}$ & $\begin{array}{l}{[0,0} \\
]\end{array}$ & $\begin{array}{l}{[0,1} \\
]\end{array}$ & $\begin{array}{l}{[1,2} \\
]\end{array}$ & $\begin{array}{l}{[1,2} \\
]\end{array}$ & $\begin{array}{l}{[1,2} \\
]\end{array}$ & ]$^{[1,2}$ & $\begin{array}{l}{[1,2} \\
]\end{array}$ & $\begin{array}{l}{[2,3} \\
]\end{array}$ & {$[0,0$} \\
\hline $\begin{array}{l}D 1 \\
2 \\
\end{array}$ & $\begin{array}{l}{[1,2} \\
]\end{array}$ & $\begin{array}{l}{[0,0} \\
] \\
\end{array}$ & $\begin{array}{l}{[2,3} \\
]\end{array}$ & $\begin{array}{l}{[2,3} \\
]\end{array}$ & $\begin{array}{l}{[2,3} \\
]\end{array}$ & $\begin{array}{l}{[2,3} \\
]\end{array}$ & $\begin{array}{l}{[3,4} \\
]\end{array}$ & $\begin{array}{l}{[2,3} \\
]\end{array}$ & $\begin{array}{l}{[0,1} \\
]\end{array}$ & ]$^{[1,2}$ & $\begin{array}{l}{[0,1} \\
]\end{array}$ & $\begin{array}{l}{[0,0} \\
]\end{array}$ & $\begin{array}{l}{[0,1} \\
]\end{array}$ & $\begin{array}{l}{[2,3} \\
]\end{array}$ & $\begin{array}{l}{[0,0} \\
]\end{array}$ & ]$^{[0,1}$ & $\begin{array}{l}{[2,3} \\
]\end{array}$ & $\begin{array}{l}{[3,4} \\
]\end{array}$ & $\begin{array}{l}{[2,3} \\
]\end{array}$ \\
\hline \begin{tabular}{|l|}
$D 1$ \\
3 \\
\end{tabular} & $\begin{array}{l}{[2,3} \\
]\end{array}$ & $\begin{array}{l}{[3,4} \\
]\end{array}$ & $\begin{array}{l}{[2,3} \\
]\end{array}$ & $\begin{array}{l}{[3,4} \\
]\end{array}$ & $\begin{array}{l}{[1,2} \\
]\end{array}$ & $\begin{array}{l}{[1,2} \\
]\end{array}$ & $\begin{array}{l}{[2,3} \\
]\end{array}$ & $\begin{array}{l}{[2,3} \\
]\end{array}$ & $\begin{array}{l}{[0,0} \\
]\end{array}$ & ]$^{[1,2}$ & $\begin{array}{l}{[1,2} \\
]\end{array}$ & $\begin{array}{l}{[0,1} \\
]\end{array}$ & $\begin{array}{l}{[0,0} \\
]\end{array}$ & $\begin{array}{l}{[1,2} \\
]\end{array}$ & $\begin{array}{l}{[2,3} \\
]\end{array}$ & {$[2,3$} & $\begin{array}{l}{[0,0} \\
]\end{array}$ & {$[1,2$} & $\begin{array}{l}{[0,0} \\
]\end{array}$ \\
\hline $\begin{array}{l}D 1 \\
4\end{array}$ & {$[1,2$} & $\begin{array}{l}{[2,3} \\
]\end{array}$ & $\begin{array}{l}{[2,3} \\
]\end{array}$ & $\begin{array}{l}{[3,4} \\
]\end{array}$ & $\begin{array}{l}{[2,3} \\
]\end{array}$ & $\begin{array}{l}{[2,3} \\
]\end{array}$ & $\begin{array}{l}{[3,4} \\
]\end{array}$ & $\begin{array}{l}{[3,4} \\
]\end{array}$ & $\begin{array}{l}{[1,2} \\
]\end{array}$ & $\begin{array}{l}{[2,3} \\
]\end{array}$ & $\begin{array}{l}{[2,3} \\
]\end{array}$ & $\begin{array}{l}{[2,3} \\
]\end{array}$ & $\begin{array}{l}{[1,2} \\
]\end{array}$ & $\begin{array}{l}{[0,0} \\
]\end{array}$ & {$[0,1$} & $\begin{array}{l}{[1,2} \\
]\end{array}$ & $\begin{array}{l}{[2,3} \\
]\end{array}$ & $\begin{array}{l}{[2,3} \\
]\end{array}$ & $\begin{array}{l}{[2,3} \\
]\end{array}$ \\
\hline
\end{tabular}




\begin{tabular}{|l|l|l|l|l|l|l|l|l|l|l|l|l|l|l|l|l|l|l|l|}
$\boldsymbol{D} 1$ & {$[0,1$} & {$[3,4$} & {$[2,3$} & {$[0,0$} & {$[0,0$} & {$[2,3$} & {$[0,1$} & {$[1,2$} & {$[1,2$} & {$[2,3$} & {$[1,2$} & {$[0,0$} & {$[2,3$} & {$[0,1$} & {$[0,0$} & {$[0,0$} & {$[1,2$} & {$[0,0$} & {$[0,0$} \\
$\mathbf{5}$ & ] & ] & ] & ] & ] & ] & ] & ] & ] & ] & ] & ] & ] & ] & ] & ] & ] & ] & ] \\
\hline $\boldsymbol{D} 1$ & {$[0,0$} & {$[1,2$} & {$[0,0$} & {$[2,3$} & {$[0,0$} & {$[0,0$} & {$[2,3$} & {$[2,3$} & {$[0,0$} & {$[0,0$} & {$[1,2$} & {$[0,1$} & {$[2,3$} & {$[1,2$} & {$[0,0$} & {$[0,0$} & {$[0,0$} & {$[2,3$} & {$[1,2$} \\
\hline $\boldsymbol{6}$ & ] & ] & ] & ] & ] & ] & ] & ] & ] & ] & ] & ] & ] & ] & ] & ] & ] & ] & ] \\
\hline $\boldsymbol{D} 1$ & {$[3,4$} & {$[0,0$} & {$[1,2$} & {$[0,0$} & {$[0,0$} & {$[2,3$} & {$[3,4$} & {$[1,2$} & {$[0,1$} & {$[0,1$} & {$[1,2$} & {$[3,4$} & {$[0,0$} & {$[2,3$} & {$[1,2$} & {$[0,0$} & {$[0,0$} & {$[2,3$} & {$[2,3$} \\
$\mathbf{7}$ & ] & ] & ] & ] & ] & ] & ] & ] & ] & ] & ] & ] & ] & ] & ] & ] & ] & ] & ] \\
\hline $\boldsymbol{D} 1$ & {$[2,3$} & {$[2,3$} & {$[3,4$} & {$[3,4$} & {$[3,4$} & {$[2,3$} & {$[3,4$} & {$[3,4$} & {$[2,3$} & {$[2,3$} & {$[2,3$} & {$[3,4$} & {$[1,2$} & {$[2,3$} & {$[0,0$} & {$[2,3$} & {$[3,4$} & {$[0,0$} & {$[3,4$} \\
$\mathbf{8}$ & ] & ] & ] & ] & ] & ] & ] & ] & ] & ] & ] & ] & ] & ] & ] & ] & ] & ] & ] \\
\hline $\boldsymbol{D} 1$ & {$[1,2$} & {$[2,3$} & {$[0,0$} & {$[0,0$} & {$[0,0$} & {$[0,0$} & {$[2,3$} & {$[0,0$} & {$[1,2$} & {$[0,0$} & {$[0,0$} & {$[2,3$} & {$[0,0$} & {$[2,3$} & {$[0,0$} & {$[1,2$} & {$[1,2$} & {$[2,3$} & {$[0,0$} \\
$\mathbf{9}$ & ] & ] & ] & ] & ] & ] & ] & ] & ] & ] & ] & ] & ] & ] & ] & ] & ] & ] & ] \\
\hline
\end{tabular}

Table-V: The Overall Direct Relationship matrix $(Y)$.

\begin{tabular}{|c|c|c|c|c|c|c|c|c|c|c|c|c|c|c|}
\hline & D1 & D2 & D3 & D4 & & & - & - & & - & D16 & D17 & D18 & D19 \\
\hline$D 1$ & {$[0,0]$} & {$[2.5,3.5]$} & {$[2,3]$} & {$[0,0]$} & {$[-\cdot-]$} & {$[\because-\cdot]$} & {$[-\cdot-]$} & {$[-.-]$} & {$[-.-]$} & {$[-\cdot-]$} & {$[0,0]$} & {$[3,4]$} & {$[2,3]$} & {$[1,2]$} \\
\hline$D 2$ & {$[3,4]$} & {$[0,0]$} & {$[3,4]$} & {$[0,0]$} & {$[-\cdot]$} & {$[-\because]$} & {$[-\cdot-]$} & {$[-\because]$} & {$[-\cdot-]$} & {$[-\cdot-]$} & {$[1,2]$} & {$[0,0]$} & {$[2,3]$} & {$[2,3]$} \\
\hline$D 3$ & {$[2,3]$} & {$[3,4]$} & {$[0,0]$} & {$[2,3]$} & {$[-\cdot]$} & {$[-\cdot-]$} & {$[-\cdot]$} & {$[-\cdot-]$} & {$[-.-]$} & {$[-\cdot-]$} & {$[0,0]$} & {$[1,2]$} & {$[2,3]$} & {$[0,0]$} \\
\hline$D 4$ & {$[0,0]$} & {$[0,0]$} & {$[2,3]$} & {$[0,0]$} & {$[-\cdot-]$} & {$\left[\begin{array}{l}-\cdot] \\
\end{array}\right.$} & {$[-\cdot-\cdot]$} & {$[-.-]$} & {$\left[\begin{array}{l}-\cdot-] \\
\end{array}\right.$} & {$[-\cdot-\cdot]$} & {$[2,3]$} & {$[0,0.5]$} & {$[3,4]$} & {$[0,0]$} \\
\hline$D 5$ & {$[0,0]$} & {$[0,0.5]$} & {$[2,3]$} & {$[2,3]$} & {$[-\cdot-]$} & {$[-\cdot-]$} & {$[-\cdot-]$} & {$[-\cdot-]$} & {$[-\cdot-]$} & {$[-\cdot-]$} & {$[0,0]$} & {$[0,0.5]$} & {$[3,4]$} & {$[0,0]$} \\
\hline$D 6$ & {$[3,4]$} & {$[0,0.5]$} & {$[2,3]$} & {$[0,0]$} & {$[-.-]$} & {$[-\cdot-]$} & {$[-\cdot-]$} & {$[--\cdot]$} & {$[-\cdot-]$} & {$[\because-\cdot]$} & {$[0,0]$} & {$[2,3]$} & {$[2,3.5]$} & {$[0,0]$} \\
\hline$D 7$ & {$[1.5,2.5]$} & {$[3,4]$} & {$[2,3]$} & {$[3,4]$} & {$[-.-]$} & {$[-\cdot-]$} & {$[-\cdot-]$} & {$[-\cdot-]$} & {$[-\cdot-]$} & {$[-\cdot-]$} & {$[2,3]$} & {$[2,3]$} & {$[2.5,4]$} & {$[2,3]$} \\
\hline$D 8$ & {$[0,0]$} & {$[0,0]$} & {$[0.5,1.5]$} & {$[2,3]$} & {$[-.-]$} & {$[-\cdot-]$} & {$[-\cdot-]$} & {$[-\cdot-]$} & {$[-.-]$} & {$[--\cdot]$} & {$[2,3]$} & {$[1,2]$} & {$[3,4]$} & {$[0,0]$} \\
\hline$D 9$ & {$[1,2]$} & {$[1.5,2.5]$} & {$[0,0]$} & {$[2,3]$} & {$[-\cdot-]$} & {$[-\cdot-]$} & {$[-\cdot-]$} & {$[\because-\cdot]$} & {$[\because--]$} & {$[-\cdot-]$} & {$[0,0]$} & {$[0,1]$} & {$[2,3]$} & {$[1,2]$} \\
\hline$D 10$ & {$[2,3]$} & {$[2,3]$} & {$[0.5,1.5]$} & {$[0,0]$} & {$[-\cdot-]$} & {$[-\cdot-]$} & {$[-\cdot-]$} & {$[-\cdot-]$} & {$[-\cdot-]$} & {$[-\cdot-]$} & {$[0,0]$} & {$[0,1]$} & {$[2,3]$} & {$[0,0]$} \\
\hline$D 11$ & {$[2,3]$} & {$[1,2]$} & {$[1,2]$} & {$[0,0]$} & {$[-\cdot-]$} & {$[--\cdot]$} & {$[-\cdot-]$} & {$[-\cdot-]$} & {$[-.-]$} & {$[-\cdot-]$} & {$[1,2]$} & {$[1,2]$} & {$[2,3]$} & {$[0,0]$} \\
\hline$D 12$ & {$[1,2]$} & {$[0,0]$} & {$[2,3]$} & {$[2,3]$} & {$[-\cdot-]$} & {$[\because-\cdot]$} & {$[-\cdot-]$} & {$[\because-\cdot]$} & {$[-.-]$} & {$[-\cdot-]$} & {$[0,1]$} & {$[2,3]$} & {$[3,4]$} & {$[2,3]$} \\
\hline$D 13$ & {$[2,3]$} & {$[3,4]$} & {$[2,3]$} & {$[3,4]$} & {$[-\cdot-]$} & {$[-\cdot-]$} & {$[-\cdot-]$} & {$[-.-]$} & {$[-\cdot-]$} & {$[-\cdot-]$} & {$[2,3]$} & {$[0,0]$} & {$[1,2]$} & {$[0,0]$} \\
\hline D14 & {$[1,2]$} & {$[2,3]$} & {$[2,3]$} & {$[3,4]$} & {$[-\cdot-]$} & {$[-\cdot-]$} & {$[-\cdot-]$} & {$[-.-]$} & {$[-.-]$} & {$[-\cdot-]$} & {$[1,2]$} & {$[2,3]$} & {$[2,3]$} & {$[2,3]$} \\
\hline$D 15$ & {$[0,1]$} & {$[3,4]$} & {$[2,3]$} & {$[0,0]$} & {$[-\cdot-]$} & {$[-\cdot-]$} & {$[-\cdot-]$} & {$[-\cdot-]$} & {$[-\cdot-]$} & {$[-\cdot-]$} & {$[0,0]$} & {$[1,2]$} & {$[0,0]$} & {$[0,0]$} \\
\hline$D 16$ & {$[0,0]$} & {$[1,2]$} & {$[0,0]$} & {$[2,3]$} & {$[-\cdot-]$} & {$[-\cdot-]$} & {$[-\cdot-]$} & {$[-\cdot-]$} & {$[-.-]$} & {$[-\cdot-]$} & {$[0,0]$} & {$[0,0]$} & {$[2,3]$} & {$[1,2]$} \\
\hline$D 17$ & {$[3,4]$} & {$[0,0]$} & {$[1,2]$} & {$[0,0]$} & {$[-\cdot-]$} & {$[-.-]$} & {$[-.-]$} & {$[-.-]$} & {$[--\cdot]$} & {$[-.-]$} & {$[0,0]$} & {$[0,0]$} & {$[2,3]$} & {$[1.5,2.5]$} \\
\hline$D 18$ & {$[2,3]$} & {$[2,3]$} & {$[2.5,3.5]$} & {$[3,4]$} & {$[-\cdot-]$} & {$[-\cdot-]$} & {$[-\cdot-]$} & {$[-\cdot-]$} & {$[-\cdot-]$} & {$[-\cdot-]$} & {$[2,3]$} & {$[2.5,3.5]$} & {$[0,0]$} & {$[3,4]$} \\
\hline D19 & {$[1,2]$} & {$[2,3]$} & {$[0,0]$} & {$[0,0]$} & {$[-\cdot-]$} & {$[--\cdot]$} & {$[-\cdot-]$} & {$[--\cdot]$} & {$[--\cdot]$} & {$[-.-]$} & {$[1,2]$} & {$[1,2]$} & {$[2.5,3.5]$} & {$[0,0]$} \\
\hline
\end{tabular}

Table -VII: The Normalized Direct - Relation Matrix $(D)$.

\begin{tabular}{|c|c|c|c|c|c|c|c|c|c|c|c|c|}
\hline & $D 1$ & D2 & D3 & D4 & - & - & - & - & D16 & $D 17$ & D18 & D19 \\
\hline$D 1$ & $\begin{array}{l}{[0.000,0.000} \\
]\end{array}$ & $\begin{array}{l}{[0.060,0.059} \\
]\end{array}$ & $\begin{array}{l}{[0.048,0.050} \\
]\end{array}$ & $\begin{array}{l}{[0.000,0.000} \\
]\end{array}$ & {$[-.-$} & {$[-\cdot-$} & {$[-.-$} & {$[-.-$} & $\begin{array}{l}{[0.000,0.000} \\
]\end{array}$ & $\begin{array}{l}{[0.072,0.067} \\
]\end{array}$ & $\begin{array}{l}{[0.048,0} \\
.050]\end{array}$ & $\begin{array}{l}{[0.024,0 .} \\
034]\end{array}$ \\
\hline$D 2$ & $\begin{array}{l}{[0.072,0.067} \\
]\end{array}$ & $\begin{array}{l}{[0.000,0.000} \\
]\end{array}$ & $\begin{array}{l}{[0.072,0.067} \\
]\end{array}$ & $\begin{array}{l}{[0.000,0.000} \\
]\end{array}$ & {$[-.-$} & {$[\cdots-$} & {$[-.-$} & {$[---$} & $\begin{array}{l}{[0.024,0.024} \\
]\end{array}$ & $\begin{array}{l}{[0.000,0.000} \\
]\end{array}$ & $\begin{array}{l}{[0.048,0} \\
.050] \\
\end{array}$ & $\begin{array}{l}{[0.048,0 .} \\
050]\end{array}$ \\
\hline D3 & $\begin{array}{l}{[0.048,0.050} \\
]\end{array}$ & $\begin{array}{l}{[0.072,0.067} \\
]\end{array}$ & $\begin{array}{l}{[0.000,0.000} \\
]\end{array}$ & $\begin{array}{l}{[0.048,0.050} \\
]\end{array}$ & {$[--\cdot$} & {$[-.-$} & {$[---$} & {$[-.-$} & $\begin{array}{l}{[0.000,0.000} \\
]\end{array}$ & $\begin{array}{l}{[0.024,0.034} \\
]\end{array}$ & $\begin{array}{l}{[0.048,0} \\
.050]\end{array}$ & $\begin{array}{l}0.000,0 . \\
000]\end{array}$ \\
\hline$D 4$ & $\begin{array}{l}{[0.000,0.000} \\
]\end{array}$ & $\begin{array}{l}{[0.000,0.000} \\
]\end{array}$ & $\begin{array}{l}{[0.048,0.050} \\
]\end{array}$ & $\begin{array}{l}{[0.000,0.000} \\
]\end{array}$ & {$[---$} & {$[-.-$} & {$[-.-$} & {$\left[\begin{array}{l}-\cdot- \\
]\end{array}\right.$} & $\begin{array}{l}{[0.048,0.048} \\
]\end{array}$ & $\begin{array}{l}{[0.000,0.008} \\
]\end{array}$ & $\begin{array}{l}{[0.072,0} \\
.067] \\
\end{array}$ & $\begin{array}{l}{[0.000,0 .} \\
000]\end{array}$ \\
\hline$D 5$ & $\begin{array}{l}{[0.000,0.000} \\
]\end{array}$ & $\begin{array}{l}{[0.000,0.008} \\
]\end{array}$ & $\begin{array}{l}{[0.048,0.050} \\
]\end{array}$ & $\begin{array}{l}{[0.048,0.050} \\
]\end{array}$ & {$[--\cdot$} & {$[-.-$} & {$[-.-$} & {$[-.-$} & $\begin{array}{l}{[0.000,0.000} \\
]\end{array}$ & $\begin{array}{l}{[0.000,0.008} \\
]\end{array}$ & $\begin{array}{l}0.072,0 \\
.067] \\
\end{array}$ & $\begin{array}{l}{[0.000,0 .} \\
000]\end{array}$ \\
\hline D6 & $\begin{array}{l}{[0.072,0.067} \\
]\end{array}$ & $\begin{array}{l}{[0.000,0.008} \\
]\end{array}$ & $\begin{array}{l}{[0.048,0.050} \\
]\end{array}$ & $\begin{array}{l}{[0.000,0.000} \\
]\end{array}$ & $\begin{array}{l}{[-.-} \\
]\end{array}$ & $\begin{array}{ll}-.- \\
]\end{array}$ & {$[-.-$} & $\begin{array}{l}{[-\cdot-} \\
]\end{array}$ & $\begin{array}{l}{[0.000,0.000} \\
]\end{array}$ & $\begin{array}{l}{[0.048,0.050} \\
]\end{array}$ & $\begin{array}{l}{[0.048,0} \\
.050] \\
\end{array}$ & $\begin{array}{l}{[0.000,0 .} \\
000]\end{array}$ \\
\hline$D 7$ & $\begin{array}{l}{[0.036,0.042} \\
]\end{array}$ & $\begin{array}{l}{[0.072,0.067} \\
]\end{array}$ & $\begin{array}{l}{[0.048,0.050} \\
]\end{array}$ & $\begin{array}{l}{[0.072,0.067} \\
]\end{array}$ & {$[-.-$} & [-.- & {$\left[\begin{array}{l}-.- \\
]\end{array}\right.$} & {$[-.-$} & $\begin{array}{l}{[0.048,0.048} \\
]\end{array}$ & $\begin{array}{l}{[0.048,0.050} \\
]\end{array}$ & $\begin{array}{l}0.060,0 \\
.059] \\
\end{array}$ & $\begin{array}{l}{[0.048,0 .} \\
050]\end{array}$ \\
\hline$D 8$ & $\begin{array}{l}{[0.000,0.000} \\
]\end{array}$ & $\begin{array}{l}{[0.000,0.000} \\
]\end{array}$ & $\begin{array}{l}{[0.012,0.025} \\
]\end{array}$ & $\begin{array}{l}{[0.048,0.050} \\
]\end{array}$ & {$[--\cdot$} & {$[-\cdot-$} & {$[-.-$} & {$[-.-$} & $\begin{array}{l}{[0.048,0.048} \\
]\end{array}$ & $\begin{array}{l}{[0.024,0.034} \\
]\end{array}$ & $\begin{array}{l}{[0.072,0} \\
.067] \\
\end{array}$ & $\begin{array}{l}{[0.000,0 .} \\
000]\end{array}$ \\
\hline$D^{9}$ & $\begin{array}{l}{[0.024,0.034} \\
]\end{array}$ & $\begin{array}{l}{[0.036,0.042} \\
]\end{array}$ & $\begin{array}{l}\text { [0.000,0.000 } \\
]\end{array}$ & $\begin{array}{l}{[0.048,0.050} \\
]\end{array}$ & {$\left[\begin{array}{l}-\cdot- \\
]\end{array}\right.$} & [-.- & [-.- & $\begin{array}{l}-\cdot- \\
]\end{array}$ & $\begin{array}{l}\text { [0.000,0.000 } \\
]\end{array}$ & $\begin{array}{l}{[0.000,0.017} \\
]\end{array}$ & $\begin{array}{l}{[0.048,0} \\
.050]\end{array}$ & $\begin{array}{l}0.024,0 . \\
034] \\
\end{array}$ \\
\hline $\begin{array}{l}D 1 \\
0 \\
\end{array}$ & $\begin{array}{l}{[0.048,0.050} \\
]\end{array}$ & $\begin{array}{l}{[0.048,0.050} \\
]\end{array}$ & $\begin{array}{l}{[0.012,0.025} \\
]\end{array}$ & $\begin{array}{l}{[0.000,0.000} \\
]\end{array}$ & {$[-.-$} & {$[-.-$} & {$[--$} & {$[-.-$} & $\begin{array}{l}{[0.000,0.000} \\
]\end{array}$ & $\begin{array}{l}{[0.000,0.017} \\
]\end{array}$ & $\begin{array}{l}{[0.048,0} \\
.050] \\
\end{array}$ & $\begin{array}{l}{[0.000,0 .} \\
000]\end{array}$ \\
\hline $\begin{array}{l}D 1 \\
1\end{array}$ & {$[0.048,0.050$} & $\begin{array}{l}{[0.024,0.034} \\
]\end{array}$ & $\begin{array}{l}{[0.024,0.034} \\
]\end{array}$ & $\begin{array}{l}{[0.000,0.000} \\
]\end{array}$ & {$[-.-$} & {$[\because--$} & {$[--$} & {$[-\cdot-$} & $\begin{array}{l}{[0.024,0.024} \\
]\end{array}$ & $\begin{array}{l}{[0.024,0.034} \\
]\end{array}$ & $\begin{array}{l}{[0.048,0} \\
.050]\end{array}$ & $\begin{array}{l}{[0.000,0 .} \\
000]\end{array}$ \\
\hline
\end{tabular}




\begin{tabular}{|c|c|c|c|c|c|c|c|c|c|c|c|c|}
\hline $\begin{array}{l}D 1 \\
2 \\
\end{array}$ & $\begin{array}{l}{[0.024,0.034} \\
]\end{array}$ & $\begin{array}{l}{[0.000,0.000} \\
]\end{array}$ & $\begin{array}{l}{[0.048,0.050} \\
]\end{array}$ & $\begin{array}{l}{[0.048,0.050} \\
]\end{array}$ & $\begin{array}{l}{[-.-} \\
]\end{array}$ & [-.- & [-.- & [-.- & $\begin{array}{l}{[0.000,0.000} \\
]\end{array}$ & $\begin{array}{l}{[0.048,0.050} \\
]\end{array}$ & $\begin{array}{l}{[0.072,0} \\
.067]\end{array}$ & $\begin{array}{l}{[0.048,0 .} \\
050]\end{array}$ \\
\hline $\begin{array}{l}11 \\
3 \\
\end{array}$ & $\begin{array}{l}{[0.048,0.050} \\
]\end{array}$ & $\begin{array}{l}{[0.072,0.067} \\
]\end{array}$ & $\begin{array}{l}{[0.048,0.050} \\
]\end{array}$ & $\begin{array}{l}{[0.072,0.067} \\
]\end{array}$ & $\begin{array}{l}{[-.-} \\
]\end{array}$ & $\begin{array}{l}{[-.-} \\
]\end{array}$ & $\begin{array}{l}{[-.-} \\
]\end{array}$ & $\begin{array}{l}{[-.-} \\
]\end{array}$ & $\begin{array}{l}{[0.048,0.048} \\
]\end{array}$ & $\begin{array}{l}{[0.000,0.000} \\
]\end{array}$ & $\begin{array}{l}{[0.024,0} \\
.034] \\
\end{array}$ & $\begin{array}{l}{[0.000,0 .} \\
000]\end{array}$ \\
\hline $\begin{array}{l}D 1 \\
4\end{array}$ & $\begin{array}{l}{[0.024,0.034} \\
]\end{array}$ & $\begin{array}{l}{[0.048,0.050} \\
]\end{array}$ & $\begin{array}{l}{[0.048,0.050} \\
]\end{array}$ & $\begin{array}{l}{[0.072,0.067} \\
]\end{array}$ & [-.- & [-.- & $\begin{array}{l}{[-.-} \\
]\end{array}$ & $\begin{array}{l}{[-.-} \\
]\end{array}$ & $\begin{array}{l}{[0.024,0.024} \\
]\end{array}$ & $\begin{array}{l}{[0.048,0.050} \\
]\end{array}$ & $\begin{array}{l}{[0.048,0} \\
.050]\end{array}$ & $\begin{array}{l}{[0.048,0 .} \\
050]\end{array}$ \\
\hline $\begin{array}{l}D 1 \\
5 \\
\end{array}$ & $\begin{array}{l}{[0.000,0.017} \\
]\end{array}$ & $\begin{array}{l}{[0.072,0.067} \\
]\end{array}$ & $\begin{array}{l}{[0.048,0.050} \\
]\end{array}$ & $\begin{array}{l}{[0.000,0.000} \\
]\end{array}$ & [-.- & $\begin{array}{l}{[-.-} \\
]\end{array}$ & $\begin{array}{l}{[-.-} \\
]\end{array}$ & $\begin{array}{l}{[-.-} \\
]\end{array}$ & $\begin{array}{l}{[0.000,0.000} \\
]\end{array}$ & $\begin{array}{l}{[0.024,0.034} \\
]\end{array}$ & $\begin{array}{l}{[0.000,0} \\
.000] \\
\end{array}$ & $\begin{array}{l}{[0.000,0 .} \\
000]\end{array}$ \\
\hline $\begin{array}{l}D 1 \\
6 \\
\end{array}$ & $\begin{array}{l}{[0.000,0.000} \\
]\end{array}$ & $\begin{array}{l}{[0.024,0.034} \\
]\end{array}$ & $\begin{array}{l}{[0.000,0.000} \\
]\end{array}$ & $\begin{array}{l}{[0.048,0.050} \\
]\end{array}$ & $\begin{array}{l}{[-.-} \\
]\end{array}$ & [-.- & $\begin{array}{l}{[-.-} \\
]\end{array}$ & $\begin{array}{l}{[-\cdot-} \\
]\end{array}$ & $\begin{array}{l}{[0.000,0.000} \\
]\end{array}$ & $\begin{array}{l}{[0.000,0.000} \\
]\end{array}$ & $\begin{array}{l}{[0.048,0} \\
.050] \\
\end{array}$ & $\begin{array}{l}{[0.024,0 .} \\
034]\end{array}$ \\
\hline $\begin{array}{l}D 1 \\
7 \\
\end{array}$ & $\begin{array}{l}{[0.072,0.067} \\
]\end{array}$ & $\begin{array}{l}{[0.000,0.000} \\
]\end{array}$ & $\begin{array}{l}{[0.024,0.034} \\
]\end{array}$ & $\begin{array}{l}{[0.000,0.000} \\
]\end{array}$ & $\begin{array}{l}{[-.-} \\
]\end{array}$ & $\begin{array}{l}{[-.-} \\
]\end{array}$ & $\begin{array}{l}{[-.-} \\
]\end{array}$ & $\begin{array}{l}{[-\cdot-} \\
]\end{array}$ & $\begin{array}{l}{[0.000,0.000} \\
]\end{array}$ & $\begin{array}{l}{[0.000,0.000} \\
]\end{array}$ & $\begin{array}{l}{[0.048,0} \\
.050]\end{array}$ & $\begin{array}{l}{[0.036,0 .} \\
042]\end{array}$ \\
\hline $\begin{array}{l}1 \\
8 \\
\end{array}$ & $\begin{array}{l}{[0.048,0.050} \\
]\end{array}$ & $\begin{array}{l}{[0.048,0.050} \\
]\end{array}$ & $\begin{array}{l}{[0.060,0.059} \\
]\end{array}$ & $\begin{array}{l}{[0.072,0.067} \\
]\end{array}$ & $\begin{array}{l}{[-.-} \\
]\end{array}$ & $\begin{array}{l}{[-.-} \\
]\end{array}$ & $\begin{array}{l}{[-.-} \\
]\end{array}$ & $\begin{array}{l}{[-.-} \\
]\end{array}$ & $\begin{array}{l}{[0.048,0.048} \\
]\end{array}$ & $\begin{array}{l}{[0.060,0.059} \\
]\end{array}$ & $\begin{array}{l}{[0.000,0} \\
.000]\end{array}$ & $\begin{array}{l}{[0.072,0 .} \\
067]\end{array}$ \\
\hline $\begin{array}{l}D 1 \\
9\end{array}$ & $\begin{array}{l}{[0.024,0.034} \\
]\end{array}$ & $\begin{array}{l}{[0.048,0.050} \\
]\end{array}$ & $\begin{array}{l}{[0.000,0.000} \\
]\end{array}$ & $\begin{array}{l}{[0.000,0.000} \\
]\end{array}$ & [-.- & $\begin{array}{l}{[-.-} \\
]\end{array}$ & $\begin{array}{l}{[-.-} \\
]\end{array}$ & $\begin{array}{l}{[-.-} \\
]\end{array}$ & $\begin{array}{l}{[0.024,0.024} \\
]\end{array}$ & $\begin{array}{l}{[0.024,0.034} \\
]\end{array}$ & $\begin{array}{l}{[0.060,0} \\
.059]\end{array}$ & $\begin{array}{l}{[0.000,0 .} \\
000]\end{array}$ \\
\hline
\end{tabular}

Table-VII. Total Influence Matrix [Tc]

\begin{tabular}{|c|c|c|c|c|c|c|c|c|c|c|c|c|}
\hline & $D 1$ & D2 & D3 & D4 & - & - & - & - & D16 & D17 & D18 & D19 \\
\hline$D 1$ & $\begin{array}{l}{[0.058,0 .} \\
076]\end{array}$ & $\begin{array}{l}{[0.110,0.13} \\
0]\end{array}$ & $\begin{array}{l}{[0.100,0.12} \\
0]\end{array}$ & $\begin{array}{l}{[0.046,0.05} \\
8]\end{array}$ & {$[-.-]$} & $\begin{array}{l}{[-.} \\
-]\end{array}$ & $\begin{array}{l}{[-.} \\
-]\end{array}$ & $\begin{array}{l}{[-.} \\
-]\end{array}$ & $\begin{array}{l}{[0.028,0.04} \\
2]\end{array}$ & $\begin{array}{l}{[0.110,0.12} \\
0]\end{array}$ & $\begin{array}{l}{[0.120,0.14} \\
0]\end{array}$ & $\begin{array}{l}{[0.059,0.08} \\
0]\end{array}$ \\
\hline D2 & $\begin{array}{l}{[0.120,0 .} \\
140]\end{array}$ & $\begin{array}{l}{[0.071,0.08} \\
1]\end{array}$ & $\begin{array}{l}{[0.130,0.14} \\
0]\end{array}$ & $\begin{array}{l}{[0.057,0.12} \\
0]\end{array}$ & {$[-.-]$} & $\begin{array}{l}-. \\
-]\end{array}$ & $\begin{array}{l}-. \\
-]\end{array}$ & $\begin{array}{l}{[-.} \\
-]\end{array}$ & $\begin{array}{l}{[0.057,0.07} \\
7]\end{array}$ & $\begin{array}{l}{[0.045,0.06} \\
1]\end{array}$ & $\begin{array}{l}{[0.120,0.14} \\
0]\end{array}$ & $\begin{array}{l}{[0.084,0.09} \\
6]\end{array}$ \\
\hline$D 3$ & $\begin{array}{l}{[0.100,0 .} \\
120]\end{array}$ & $\begin{array}{l}{[0.130,0.14} \\
0]\end{array}$ & $\begin{array}{l}{[0.066,0.08} \\
5]\end{array}$ & $\begin{array}{l}{[0.100,0.10} \\
0]\end{array}$ & {$[-.]$.} & $\begin{array}{l}{[-.} \\
-]\end{array}$ & $\begin{array}{l}{[-.} \\
-]\end{array}$ & $\begin{array}{l}{[-.} \\
-]\end{array}$ & $\begin{array}{l}{[0.035,0.04} \\
9]\end{array}$ & $\begin{array}{l}{[0.069,0.09} \\
7]\end{array}$ & $\begin{array}{l}{[0.130,0.15} \\
0]\end{array}$ & $\begin{array}{l}{[0.039,0.05} \\
0]\end{array}$ \\
\hline D4 & $\begin{array}{l}{[0.047,0 .} \\
060]\end{array}$ & $\begin{array}{l}{[0.056,0.06} \\
5]\end{array}$ & $\begin{array}{l}{[0.100,0.12} \\
0]\end{array}$ & $\begin{array}{l}{[0.069,0.04} \\
7]\end{array}$ & {$[-.-]$} & $\begin{array}{l}{[-.} \\
-]\end{array}$ & $\begin{array}{l}{[-.} \\
-]\end{array}$ & $\begin{array}{l}{[-.} \\
-]\end{array}$ & $\begin{array}{l}{[0.084,0.09} \\
5]\end{array}$ & $\begin{array}{l}{[0.042,0.06} \\
3]\end{array}$ & $\begin{array}{l}{[0.150,0.15} \\
0]\end{array}$ & $\begin{array}{l}{[0.039,0.04} \\
6]\end{array}$ \\
\hline D5 & $\begin{array}{l}{[0.036,0 .} \\
050]\end{array}$ & $\begin{array}{l}{[0.040,0.05} \\
9]\end{array}$ & $\begin{array}{l}{[0.091,0.11} \\
0]\end{array}$ & $\begin{array}{l}{[0.097,0.03} \\
6]\end{array}$ & {$[-.-]$} & $\begin{array}{l}{[-.} \\
-]\end{array}$ & $\begin{array}{l}{[-.} \\
-]\end{array}$ & $\begin{array}{l}{[-.} \\
-]\end{array}$ & $\begin{array}{l}{[0.029,0.03} \\
9]\end{array}$ & $\begin{array}{l}{[0.033,0.05} \\
5]\end{array}$ & $\begin{array}{l}{[0.130,0.14} \\
0]\end{array}$ & $\begin{array}{l}{[0.030,0.03} \\
8]\end{array}$ \\
\hline D6 & $\begin{array}{l}{[0.120,0 .} \\
130]\end{array}$ & $\begin{array}{l}{[0.055,0.07} \\
8]\end{array}$ & $\begin{array}{l}{[0.100,0.12} \\
0]\end{array}$ & $\begin{array}{l}{[0.052,0.12} \\
0]\end{array}$ & \begin{tabular}{|l}
{$[-.-]$} \\
\end{tabular} & $\begin{array}{l}{[-.} \\
-]\end{array}$ & $\begin{array}{l}{[-.} \\
-]\end{array}$ & $\begin{array}{l}{[-.} \\
-]\end{array}$ & $\begin{array}{l}{[0.029,0.04} \\
2]\end{array}$ & $\begin{array}{l}{[0.092,0.11} \\
0]\end{array}$ & $\begin{array}{l}{[0.120,0.14} \\
0]\end{array}$ & $\begin{array}{l}{[0.036,0.04} \\
7]\end{array}$ \\
\hline$D 7$ & $\begin{array}{l}{[0.120,0 .} \\
140]\end{array}$ & $\begin{array}{l}{[0.150,0.16} \\
0]\end{array}$ & $\begin{array}{l}{[0.140,0.16} \\
0]\end{array}$ & $\begin{array}{l}{[0.150,0.12} \\
0]\end{array}$ & {$[-.-]$} & $\begin{array}{l}{[-\cdot} \\
-]\end{array}$ & $\begin{array}{l}{[-\cdot} \\
-]\end{array}$ & $\begin{array}{l}{[-.} \\
-]\end{array}$ & $\begin{array}{l}{[0.097,0.12} \\
0]\end{array}$ & $\begin{array}{l}{[0.110,0.14} \\
0]\end{array}$ & $\begin{array}{l}{[0.180,0.20} \\
0]\end{array}$ & $\begin{array}{l}{[0.100,0.12} \\
0]\end{array}$ \\
\hline D8 & $\begin{array}{l}{[0.045,0 .} \\
064]\end{array}$ & $\begin{array}{l}{[0.051,0.06} \\
6]\end{array}$ & $\begin{array}{l}{[0.068,0.09} \\
8]\end{array}$ & $\begin{array}{l}{[0.110,0.04} \\
5]\end{array}$ & {$[-.-]$} & $\begin{array}{l}{[-.} \\
-]\end{array}$ & $\begin{array}{l}{[-.} \\
-]\end{array}$ & $\begin{array}{l}{[-.} \\
-]\end{array}$ & $\begin{array}{l}{[0.081,0.09} \\
5]\end{array}$ & $\begin{array}{l}{[0.064,0.09} \\
1]\end{array}$ & $\begin{array}{l}{[0.140,0.16} \\
0]\end{array}$ & $\begin{array}{l}{[0.038,0.04} \\
8]\end{array}$ \\
\hline$D 9$ & $\begin{array}{l}{[0.063,0 .} \\
093]\end{array}$ & $\begin{array}{l}{[0.077,0.10} \\
0]\end{array}$ & $\begin{array}{l}{[0.046,0.06} \\
8]\end{array}$ & $\begin{array}{l}{[0.086,0.06} \\
3]\end{array}$ & {$[-.-]$} & $\begin{array}{l}{[-.} \\
-]\end{array}$ & $\begin{array}{l}{[-.} \\
-]\end{array}$ & $\begin{array}{l}{[-.} \\
-]\end{array}$ & $\begin{array}{l}{[0.028,0.04} \\
2]\end{array}$ & $\begin{array}{l}{[0.033,0.07} \\
1]\end{array}$ & $\begin{array}{l}{[0.110,0.13} \\
0]\end{array}$ & $\begin{array}{l}{[0.052,0.07} \\
4]\end{array}$ \\
\hline $\begin{array}{l}D 1 \\
0\end{array}$ & $\begin{array}{l}{[0.090,0 .} \\
110]\end{array}$ & $\begin{array}{l}{[0.095,0.11} \\
0]\end{array}$ & $\begin{array}{l}{[0.060,0.09} \\
1]\end{array}$ & $\begin{array}{l}{[0.041,0.09} \\
0]\end{array}$ & {$[-.-]$} & $\begin{array}{l}{[-.} \\
-]\end{array}$ & $\begin{array}{l}{[-.} \\
-]\end{array}$ & $\begin{array}{l}{[-.} \\
-]\end{array}$ & $\begin{array}{l}{[0.026,0.03} \\
9]\end{array}$ & $\begin{array}{l}{[0.036,0.07} \\
1]\end{array}$ & $\begin{array}{l}{[0.100,0.13} \\
0]\end{array}$ & $\begin{array}{l}{[0.031,0.04} \\
3]\end{array}$ \\
\hline $\begin{array}{l}D 1 \\
1\end{array}$ & $\begin{array}{l}{[0.093,0 .} \\
120]\end{array}$ & $\begin{array}{l}{[0.074,0.10} \\
0]\end{array}$ & $\begin{array}{l}{[0.070,0.10} \\
0]\end{array}$ & $\begin{array}{l}{[0.044,0.09} \\
3]\end{array}$ & {$[-.-]$} & $\begin{array}{l}{[-.} \\
-]\end{array}$ & $\begin{array}{l}{[-.} \\
-]\end{array}$ & $\begin{array}{l}{[-.} \\
-]\end{array}$ & $\begin{array}{l}{[0.048,0.07} \\
2]\end{array}$ & $\begin{array}{l}{[0.059,0.09} \\
0]\end{array}$ & $\begin{array}{l}{[0.110,0.13} \\
0]\end{array}$ & $\begin{array}{l}{[0.031,0.04} \\
6]\end{array}$ \\
\hline $\begin{array}{l}D 1 \\
2\end{array}$ & $\begin{array}{l}{[0.074,0 .} \\
100]\end{array}$ & $\begin{array}{l}{[0.052,0.07} \\
0]\end{array}$ & $\begin{array}{l}{[0.100,0.13} \\
0]\end{array}$ & $\begin{array}{l}{[0.100,0.07} \\
4]\end{array}$ & {$[-.-]$} & $\begin{array}{l}{[-.} \\
-]\end{array}$ & $\begin{array}{l}{[-.} \\
-]\end{array}$ & $\begin{array}{l}{[-.} \\
-]\end{array}$ & $\begin{array}{l}{[0.034,0.06} \\
5]\end{array}$ & $\begin{array}{l}{[0.092,0.11} \\
0]\end{array}$ & $\begin{array}{l}{[0.150,0.17} \\
0]\end{array}$ & $\begin{array}{l}{[0.085,0.09} \\
8]\end{array}$ \\
\hline $\begin{array}{l}D 1 \\
3\end{array}$ & $\begin{array}{l}{[0.093,0 .} \\
110]\end{array}$ & $\begin{array}{l}{[0.120,0.13} \\
0]\end{array}$ & $\begin{array}{l}{[0.100,0.13} \\
0]\end{array}$ & $\begin{array}{l}{[0.120,0.09} \\
3]\end{array}$ & {$[-.-]$} & $\begin{array}{l}{[-.} \\
-]\end{array}$ & $\begin{array}{l}{[-.} \\
-]\end{array}$ & $\begin{array}{l}{[-.} \\
-]\end{array}$ & $\begin{array}{l}{[0.079,0.09} \\
5]\end{array}$ & $\begin{array}{l}{[0.037,0.05} \\
8]\end{array}$ & $\begin{array}{l}{[0.095,0.13} \\
0]\end{array}$ & $\begin{array}{l}{[0.032,0.04} \\
5]\end{array}$ \\
\hline $\begin{array}{l}D 1 \\
4 \\
\end{array}$ & $\begin{array}{l}{[0.090,0 .} \\
120]\end{array}$ & $\begin{array}{l}{[0.110,0.13} \\
0]\end{array}$ & $\begin{array}{l}{[0.120,0.14} \\
0]\end{array}$ & $\begin{array}{l}{[0.140,0.09} \\
0]\end{array}$ & {$[-.]$.} & $\begin{array}{l}{[-\cdot} \\
-]\end{array}$ & $\begin{array}{l}{[-\cdot} \\
-]\end{array}$ & $\begin{array}{l}{[-.} \\
-]\end{array}$ & $\begin{array}{l}{[0.067,0.09} \\
2]\end{array}$ & $\begin{array}{l}{[0.100,0.12} \\
0]\end{array}$ & $\begin{array}{l}{[0.150,0.17} \\
0]\end{array}$ & $\begin{array}{l}{[0.093,0.11} \\
0]\end{array}$ \\
\hline $\begin{array}{l}D 1 \\
5\end{array}$ & $\begin{array}{l}{[0.036,0 .} \\
069]\end{array}$ & $\begin{array}{l}{[0.100,0.11} \\
0]\end{array}$ & $\begin{array}{l}{[0.080,0.10} \\
0]\end{array}$ & $\begin{array}{l}{[0.026,0.03} \\
6]\end{array}$ & {$[-.-]$} & $\begin{array}{l}{[-.} \\
-]\end{array}$ & $\begin{array}{l}{[-.} \\
-]\end{array}$ & $\begin{array}{l}{[-.} \\
-]\end{array}$ & $\begin{array}{l}{[0.017,0.02} \\
9]\end{array}$ & $\begin{array}{l}{[0.043,0.07} \\
2]\end{array}$ & $\begin{array}{l}{[0.041,0.06} \\
3]\end{array}$ & $\begin{array}{l}{[0.017,0.02} \\
9]\end{array}$ \\
\hline $\begin{array}{l}D 1 \\
6 \\
\end{array}$ & $\begin{array}{l}{[0.029,0 .} \\
043]\end{array}$ & $\begin{array}{l}{[0.056,0.07} \\
7]\end{array}$ & $\begin{array}{l}{[0.035,0.05} \\
0]\end{array}$ & $\begin{array}{l}{[0.084,0.02} \\
9]\end{array}$ & {$[-.-]$} & $\begin{array}{l}{[-.} \\
-]\end{array}$ & $\begin{array}{l}{[-.} \\
-]\end{array}$ & $\begin{array}{l}{[-.} \\
-]\end{array}$ & $\begin{array}{l}{[0.026,0.03} \\
7]\end{array}$ & $\begin{array}{l}{[0.024,0.03} \\
8]\end{array}$ & $\begin{array}{l}{[0.093,0.11} \\
0]\end{array}$ & $\begin{array}{l}{[0.046,0.06} \\
4]\end{array}$ \\
\hline $\begin{array}{l}D 1 \\
7 \\
\end{array}$ & $\begin{array}{l}{[0.110,0 .} \\
130]\end{array}$ & $\begin{array}{l}{[0.046,0.06} \\
2]\end{array}$ & $\begin{array}{l}{[0.072,0.09} \\
8]\end{array}$ & $\begin{array}{l}{[0.043,0.11} \\
0]\end{array}$ & {$[-.-]$} & $\begin{array}{l}{[-.} \\
-]\end{array}$ & $\begin{array}{l}{[-.} \\
-]\end{array}$ & $\begin{array}{l}{[-\cdot} \\
-]\end{array}$ & $\begin{array}{l}{[0.025,0.03} \\
8]\end{array}$ & $\begin{array}{l}{[0.043,0.05} \\
9]\end{array}$ & $\begin{array}{l}{[0.110,0.13} \\
0]\end{array}$ & $\begin{array}{l}{[0.068,0.08} \\
4]\end{array}$ \\
\hline $\begin{array}{l}D 1 \\
8 \\
\end{array}$ & $\begin{array}{l}0.120,0 . \\
140]\end{array}$ & $\begin{array}{l}{[0.120,0.14} \\
0]\end{array}$ & $\begin{array}{l}{[0.140,0.16} \\
0]\end{array}$ & $\begin{array}{l}{[0.150,0.12} \\
0]\end{array}$ & {$[-.-]$} & $\begin{array}{l}{[-.} \\
-]\end{array}$ & $\begin{array}{l}{[-.} \\
-]\end{array}$ & $\begin{array}{l}{[-\cdot} \\
-]\end{array}$ & $\begin{array}{l}{[0.095,0.11} \\
0]\end{array}$ & $\begin{array}{l}{[0.120,0.14} \\
0]\end{array}$ & $\begin{array}{l}{[0.120,0.14} \\
0]\end{array}$ & $\begin{array}{l}{[0.120,0.13} \\
0]\end{array}$ \\
\hline $\begin{array}{l}D 1 \\
9\end{array}$ & $\begin{array}{l}{[0.057,0 .} \\
079]\end{array}$ & $\begin{array}{l}{[0.081,0.09} \\
4]\end{array}$ & $\begin{array}{l}{[0.038,0.04} \\
9]\end{array}$ & $\begin{array}{l}{[0.037,0.05} \\
7]\end{array}$ & {$[-.-]$} & $\begin{array}{l}{[-.} \\
-]\end{array}$ & $\begin{array}{l}{[-.} \\
-]\end{array}$ & $\begin{array}{l}{[-\cdot} \\
-]\end{array}$ & $\begin{array}{l}{[0.045,0.06} \\
3]\end{array}$ & $\begin{array}{l}{[0.053,0.07} \\
4]\end{array}$ & $\begin{array}{l}{[0.110,0.12} \\
0]\end{array}$ & $\begin{array}{l}{[0.030,0.03} \\
9]\end{array}$ \\
\hline
\end{tabular}

Table-VIII: Prominence and Relation and Cause and Effect of Factors

\begin{tabular}{|c|c|c|c|c|c|}
\hline & D & $\mathbf{R}$ & $\mathbf{D}+\mathrm{R}$ & D-R & Cause/Effect \\
\hline D1 & {$[1.471,1.866]$} & {$[1.501,1.894]$} & {$[2.972,3.760]$} & {$[-0.03,-0.028]$} & Effect \\
\hline D2 & {$[1.632,1.916]$} & {$[1.594,1.902]$} & {$[3.226,3.818]$} & {$[0.038,0.014]$} & Cause \\
\hline D3 & {$[1.627,2.049]$} & {$[1.656,2.069]$} & {$[3.283,4.118]$} & {$[-0.029,-0.02]$} & Effect \\
\hline D4 & {$[1.563,1.778]$} & {$[1.552,1.772]$} & {$[3.115,3.550]$} & {$[0.011,0.006]$} & Cause \\
\hline D5 & {$[1.159,1.46]$} & {$[1.157,1.394]$} & {$[2.316,2.854]$} & {$[0.002,0.066]$} & Cause \\
\hline D6 & {$[1.447,1.833]$} & {$[1.443,1.817]$} & {$[2.890,3.650]$} & {$[0.004,0.016]$} & \\
\hline \multicolumn{3}{|c|}{$\begin{array}{l}\text { Retrieval Number: D10431292S219/2019@BEIESP } \\
\text { DOI:10.35940/ijrte.D1043.1284S219 }\end{array}$} & \multicolumn{2}{|c|}{$\begin{array}{l}\text { Published By: } \\
\text { Blue Eyes Intelligence Engineering } \\
\text { \& Sciences Publication }\end{array}$} & \\
\hline
\end{tabular}


Examination Corporate Social Responsibility Factors for Supply Chain Management Implementation using GREY-DEMATEL Method

\begin{tabular}{|c|c|c|c|c|c|}
\hline D7 & {$[2.457,2.817]$} & {$[2.477,2.836]$} & {$[4.934,5.653]$} & {$[-0.02,-0.019]$} & Effect \\
\hline D8 & {$[1.475,1.854]$} & {$[1.538,1.897]$} & {$[3.013,3.751]$} & {$[-0.063,-0.043]$} & Effect \\
\hline D9 & {$[1.204,1.681]$} & {$[1.188,1.668]$} & {$[2.392,3.349]$} & {$[0.016,0.013]$} & Cause \\
\hline D10 & {$[1.223,1.63]$} & {$[1.233,1.632]$} & {$[2.456,3.262]$} & {$[-0.01,-0.002]$} & Effect \\
\hline D11 & {$[1.304,1.78]$} & {$[1.265,1.766]$} & {$[2.569,3.546]$} & {$[0.039,0.014]$} & Cause \\
\hline D12 & {$[1.546,1.995]$} & {$[1.597,2.032]$} & {$[3.143,4.027]$} & {$[-\mathbf{0 . 0 5 1}, \mathbf{- 0 . 0 3 7 ]}$} & Effect \\
\hline D13 & {$[1.46,1.907]$} & {$[1.496,1.925]$} & {$[2.956,3.832]$} & {$[-0.036,-0.018]$} & Effect \\
\hline D14 & {$[2.017,2.45]$} & {$[1.967,2.396]$} & {$[3.984,4.846]$} & {$[0.05,0.054]$} & Cause \\
\hline D15 & {$[0.885,1.303]$} & {$[0.909,1.341]$} & {$[1.794,2.644]$} & {$[-0.024,-0.038]$} & Effect \\
\hline D16 & {$[0.931,1.245]$} & {$[0.93,1.241]$} & {$[1.861,2.486]$} & {$[0.001,0.004]$} & Cause \\
\hline D17 & {$[1.267,1.644]$} & {$[1.205,1.64]$} & {$[2.472,3.284]$} & {$[0.062,0.004]$} & Cause \\
\hline D18 & {$[2.37,2.707]$} & {$[2.279,2.643]$} & {$[4.649,5.350]$} & {$[0.091,0.064]$} & Cause \\
\hline D19 & {$[0.979,1.237]$} & {$[1.03,1.287]$} & {$[2.009,2.524]$} & {$[-0.051,-0.05]$} & Effect \\
\hline
\end{tabular}

